\title{
Social Aspects in the Assessment of Biobased Value Chains
}

\author{
Nirvana Angela Marting Vidaurre*(D, Ricardo Vargas-Carpintero, Moritz Wagner ${ }^{(D}$, Jan Lask (D) \\ and Iris Lewandowski
}

Department of Biobased Resources in the Bioeconomy, University of Hohenheim, 70599 Stuttgart, Germany; ricardo.vargas@uni-hohenheim.de (R.V.-C.); moritz.wagner@uni-hohenheim.de (M.W.); jan.lask@uni-hohenheim.de (J.L.); iris_lewandowski@uni-hohenheim.de (I.L.)

* Correspondence: nirvanaa.marting@uni-hohenheim.de

Received: 29 August 2020; Accepted: 19 November 2020; Published: 25 November 2020

\begin{abstract}
Social Life-Cycle Assessment (S-LCA) is under continuous development. The Methodological Sheets for Subcategories in S-LCA are a set of guidelines commonly used for the performance of such assessments. They cover a variety of stakeholders and subcategories for the social assessment of products in general. However, they may not necessarily be appropriate for the assessment of biobased value chains of agricultural and forestry origin. The aim of this study is the identification of social aspects relevant for the assessment of biobased value chains across various regions of the world, including those aspects possibly overlooked in the Methodological Sheets for Subcategories in S-LCA. For this purpose, a literature review of empirical studies was performed using the sheets as a reference. The results show that the Methodological Sheets for Subcategories in S-LCA provide good coverage of social topics relevant for biobased value chains, but that the stakeholders "smallholder" and "family farm" are not adequately addressed. Drawing on the empirical literature reviewed, the study emphasizes the relevance of these stakeholders in the analysis of biobased value chains of agricultural and forestry origin, and proposes criteria for consideration in the assessment of this stakeholder.
\end{abstract}

Keywords: social sustainability; social life-cycle assessment; S-LCA; biobased value chain

\section{Introduction}

The increase in biobased products, including food and feed, leads to a higher demand for biomass. Biomass scenarios have shown that, by 2050, global biomass demand for food, feed, materials, and energy could be 10 billion tons (dry matter) higher than the approximately 12 billion tons used in 2011 [1]. In addition, the increasing number of national bioeconomy strategies demonstrates the growing political will in various regions of the world to encourage the production of biobased products. As of 2018, 49 countries had established such bioeconomy strategies [2].

Contrary to common belief, the production of biomass and bioproducts is not sustainable per se [3]. Its sustainability needs to be assessed from a holistic perspective, encompassing not only economic and environmental, but also social sustainability [3,4]. In the past years, positive social impacts have been attributed to the production of biobased products. These include job creation [5], higher household income in rural communities [6,7], improved agricultural techniques, greater access to energy in rural areas [8], and stronger social responsibility practices [9]. However, this does not mean that the production of bioproducts is always socially sustainable. A clear example is the production of first generation biofuels, the sustainability of which has been widely criticized, among other things, for its social consequences. First-generation biofuels have been associated with an increase in the price of agricultural commodities $[10,11]$ and with working conditions that do not comply with the 
International Labour Organization (ILO) conventions [8] and land rights issues [12]. Even their role in rural development has been questioned [13].

Some methodologies used to analyze social sustainability are Social Impact Assessment (SIA), Socio-Economic Impact Assessment (SEIA), and Social Life Cycle Assessment (S-LCA) [14]. Unlike the other methodologies, S-LCA aims to assess the social sustainability of products throughout their lifecycle. S-LCA has its origins in the life-cycle thinking approach and Life-Cycle Assessment (LCA) [15]. LCA is a framework to account for the environmental impacts throughout a product's life-cycle (from cradle to grave) [16,17]. In a similar way, S-LCA aims to account for the social impacts of products in a systematic form [15]. In 2006, experts acknowledged the need to create a framework for the assessment of social sustainability [15]. In 2009, the United Nations Environment Programme (UNEP) and the Society of Environmental Toxicology and Chemistry (SETAC) Life Cycle Initiative developed guidelines for the S-LCA of products, a document containing a comprehensive approach and impact categories that serves as guidance for practitioners performing a S-LCA [15,18]. In 2013, the UNEP/SETAC published the Methodological Sheets for Subcategories in S-LCA [19] (hereafter referred to as 'the sheets'). They contain stakeholders, impact subcategories and indicators for the evaluation of products. The proposed stakeholders are "workers", "local community", "value chain actors", "society", and "consumers". There is a set of impact subcategories for each stakeholder. The impact subcategories are important topics in a social sense [15] and have their origin in principles established by international agreements and standards such as the Universal Declaration of Human Rights and the ILO conventions.

The guidelines for S-LCA of products have been under revision in the last few years and an overview of the latest draft version [20] was presented at the 7th Social LCA conference, which took place from 15-17 June 2020 in Gothenburg with virtual participation. In the revised version, the stakeholder "children" was added to the list of suggested stakeholders. A number of new subcategories were also added, including "poverty alleviation" and "ethical treatment of animals", both relevant subcategories for biobased value chains. However, the sheets for S-LCA were developed for the analysis of products in general, not specifically for biobased products. Unlike other products, biobased products-especially those with forestry and agricultural origin-come from land-based systems and thus involve direct interaction of processing companies with land workers and landowners. Agriculture and forestry form a significant part of the bioeconomy, representing the largest sectors of primary production, followed by fishery, aquaculture and algae and microorganisms [21]. At a global scale, approximately 4900 million hectares (Mha) of land surface is dedicated to agriculture ( $33 \%$ global land surface) and 3900 Mha is forest [21]. According to ILO, agriculture employed 1.1 billion people (31\% of worldwide employment) in 2013, while the forestry sector accounts for 13.7 million formal jobs [22]. Due to the anticipated increase in global biomass demand and the relevance of these sectors in the bioeconomy, it is crucial that S-LCAs cover social topics that are relevant to biomass production in these sectors.

Various review studies associated with social aspects in biobased value chains were identified in the literature. These reviews vary according to their aim and scope. Some of them, like [4] and [14], contain an evaluation of the indicators proposed by frameworks widely used in the biobased economy, including UNEP-SETAC [15] and Global Bioenergy Partnership (GBEP) [23], Global-Bio-Pact [24], and BioSTEP [25]. Both studies also analyzed social assessments, one reviewing the methods most often applied for social impact assessment [14], and the other identifying the most relevant aspects for the specific stakeholder consumer [4]. In addition, Ref. [4] went a step further by assessing the relevance of these social aspects in an expert workshop. In a similar way, Ref. [26] reviewed the existing body of scientific Life-Cycle Assessment studies, but with a focus on European countries, also assessing the relevance of the social indicators identified in a workshop. Some reviews focused on a specific sector of the bioeconomy [27]. However, review studies focused on the analysis of empirical peer-reviewed literature of the last years and a global scope are scarce to the knowledge of the author. Empirical studies perform analyses at an operational level and seek to measure impacts 
using various methods that can be qualitative or quantitative. By contrast, conceptual studies seek to establish a common language among assessments [12]. As a consequence, many of these propose criteria to evaluate the social impacts but do not collect empirical information. While conceptual studies cover a large number of social aspects, empirical studies tend to cover only a limited number of aspects, indicating that the assessment of social sustainability is still at the beginning of its development [12].

This study aims to answer the following research questions: (1) Which social aspects were reported and assessed in empirical studies of agricultural and forestry-based value chains in the various regions of the world during the last years? (2) To what extent are these aspects covered by the Methodological Sheets for S-LCA? The assessment and reporting of social aspects in empirical literature on biobased value chains may point to relevant topics to be considered when evaluating these types of value chains. To answer these questions, we first carry out a literature review of empirical studies covering social impacts of agricultural and forestry value chains to identify social aspects that are often assessed and reported. Secondly, we use the Methodological Sheets for Subcategories in S-LCA as a reference to allocate the social aspects reported and evaluated by empirical literature and review studies to those impact subcategories proposed by the sheets. This enables the identification of social aspects often assessed and those potentially overlooked in the sheets. To provide information on the context where the social aspects were identified, the results are also presented according to region and feedstock.

The Methodological Sheets for Subcategories in S-LCA were chosen as a reference for this study due to their relevance in S-LCA, their comprehensiveness and clear structure, and their broad application among practitioners. The sheets provide a thorough coverage of social aspects (31 impact subcategories) and stakeholders (five groups). In addition, a bibliometric analysis of S-LCA studies published by [28] reveals that 66\% of all S-LCA articles were published between 2015 and 2018 . This shows that the number of S-LCA studies increased significantly after the publication of the UNEP/SETAC Guidelines in 2009 and the sheets in 2013 [28], and may be an indication of the relevance of such documents in the field of S-LCA.

Finally, based on the compiled information, we propose a set of social aspects which are likely to be relevant and should thus be included in any S-LCA of a product of agricultural or forestry origin.

The review presented here is different from those described above in that it has a global focus with studies spanning numerous regions of the world, builds on empirical peer-reviewed literature with a focus on bottom-up approaches, covers distinct methods (not only S-LCAs), and focuses on the latest body of literature. Its particularity can be seen in its focus on the biomass production stage, building on empirical case studies. Furthermore, the content of the review is built on examples from the literature with the aim of illustrating social aspects through real case studies. It is essential to emphasize that this review does not neglect the relevance of context specificity in social assessments but aims to contribute to the understanding of social aspects in the S-LCA of biobased value chains. The contribution of this article is: first-to provide a general overview of common social issues encountered in biomass production in land-based systems, illustrated by examples from case studies; secondly, to provide an overview of social aspects assessed in case studies according to world region and feedstock; finally, to offer a starting point for practitioners who wish to assess the stakeholder "smallholder/family farm" in the S-LCA of agricultural and forestry value chains. This article is targeted at bioeconomy community members interested in sustainability assessment.

\section{Methods}

The methodology followed to answer the research question consists of two steps. The first step is the selection of articles for review and the second step the extraction of social aspects and their further allocation according to the structure of the sheets. For the literature review, first a search was performed using key strings including the term soci*, impact*, and bio*. This was followed by a second search including the term sust*. The reason for the addition of a second string was that it was noticed that a relevant body of literature was available under the term "sust". Only four duplicates were identified when comparing both lists of articles. Table 1 presents an overview of the search 
strings used. The articles included were peer-reviewed publications written in English and published between 2016 and 2019. This timespan was chosen in order to review the latest body of literature and to target literature published after the United Nations had defined the Sustainable Development Goals and the Paris Agreement on Climate Change had been established, both of which took place in 2015 and emphasize the importance of a holistic sustainable development and bioeconomy expansion. The search engine used was Scopus.

Table 1. Key strings used for the literature search.

\begin{tabular}{|c|c|c|}
\hline Search Number & String & Number of Records \\
\hline Search 1 & $\begin{array}{l}\text { soci* AND (issue* OR impact* OR effect* OR consequence }^{*} \text { OR repercu* } \\
\text { OR burden* OR influenc* OR assess* OR analys* OR benefit }{ }^{*} \text { ) AND (bio* } \\
\text { OR farm* OR agri* OR rural OR cultiv* OR crop) }\end{array}$ & 767 \\
\hline Search 2 & sust* AND bio* AND social & 887 \\
\hline
\end{tabular}

The searches resulted in a total of 1654 articles. From this, 42 articles were selected for analysis. Thirty-nine of these articles involve case studies and three are reviews involving case studies. Figure 1 shows the selection process.

The criteria for inclusion of the articles is described as follows. In general, biomass can be derived from a range of sources including non land-based (for example, algae, fishery), and land-based systems (forestry, agriculture) [29]. In particular, this review focuses on land-based systems for growing multipurpose crops and for providing biomass for energy and materials. Furthermore, the included articles are case studies which empirically assessed social impacts on stakeholders in agricultural and forestry value chains. When deciding whether to include or exclude articles, the following questions were asked:

- Is the article related to an agricultural or forestry value chain? This excluded, for example, algae and fishery.

- Does the article contain case studies?

- Does the article cover a social assessment?

- Is the feedstock (assessed by the study) a potential source of materials or energy (and if applicable) in addition to food?

A complete list of the articles included is given in Table A1. An analysis of the eligible articles enabled the identification of social aspects that are either reported or are modeled and assessed in the production of biomass and biobased products. The social aspects identified were then matched with those proposed in the sheets for subcategories in S-LCA. These include social subcategories such as "health and safety", "fair salary", and "community engagement". The categories are defined and established for five groups of stakeholders: "workers", "local community", "consumers", "society", and "value chain actors". An overview of the sheets is provided in Table A2. Social aspects identified in the literature were, where possible, classified according to the groups and categories proposed in the sheets. If a social aspect did not match any of the classes, it was included in a separate table (see Table 7). 


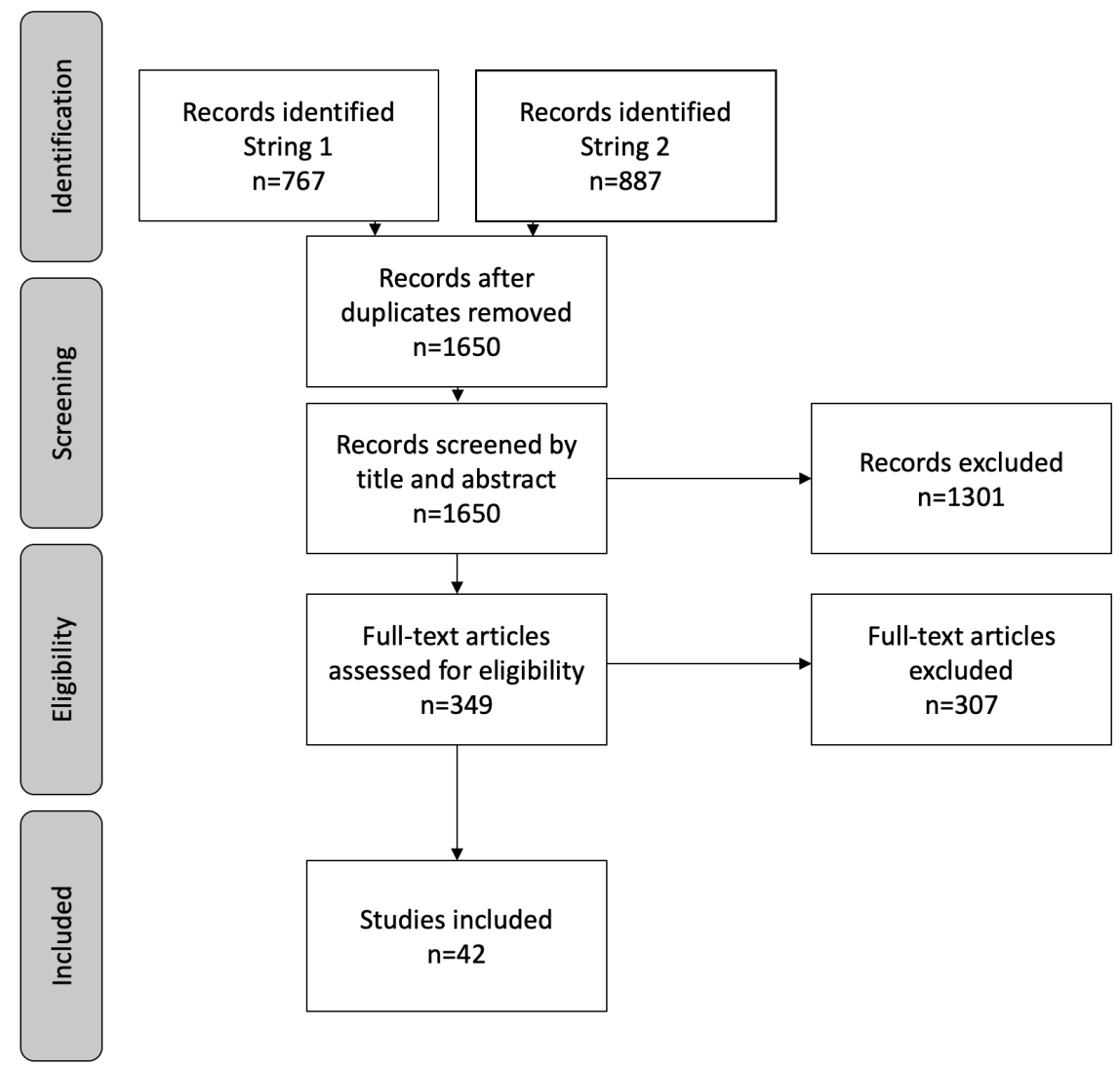

Figure 1. Selection process, diagram adapted from PRISMA [30].

\section{Results}

This section is divided into three subsections. The first gives a summary of the social aspects covered by the analyzed literature according to world region and feedstock. Section 3.2 presents the results of the analysis according to the stakeholder affected, following the structure of subcategories and stakeholders proposed in the sheets. As the stakeholder "smallholder farmer" is commonly addressed in the literature reviewed but is not covered in the sheets, a characterization of this stakeholder is included here. Finally, Section 3.3 discusses aspects overlooked in the sheets.

\subsection{Social Aspects Assessed and/or Reported in the Literature of Biobased Value Chains According to Feedstock} and World Region

The results of the literature review are summarized in Table 2. The classification of geographic regions adopts the country grouping presented by the United Nations [31] for the reporting of information on SDG indicators. In addition to a countries' geography, this grouping also takes their level of development into account. Based on the results of the literature review, the regions included in this study are: Central and Southern Asia, Eastern and South Eastern Asia, sub-Saharan Africa, Europe and Northern America, and Latin America. The feedstocks covered are: agricultural residues, cassava, cotton, forest biomass, grass, integrated systems (e.g., agroforestry), jatropha, manure and biogas biomass, oil palm, roselle and trau, rubber, soybean, sugarcane, switchgrass, wheat and maize.

Asia is the region with the highest number of studies (Central and Southern Asia [32-37], Eastern and South Eastern Asia [38-43]), covering six of these feedstocks. Sugarcane [44-48], oil palm [39,40,49,50] and biomass for biogas (manure and residues) [35-38,51,52] are the feedstocks that are assessed in the highest number of world regions. For example, social assessments of palm oil were performed in Eastern and South Eastern Asia, Latin America, and sub-Saharan Africa. Sugarcane is the feedstock with the highest number of assessed social aspects, including income, 
child labor, forced labor, gender equality, cultural heritage, local employment, access to material resources, smallholder farmer inclusiveness in the markets, supplier relationships, and health and safety. In Europe and Northern America, forest biomass is the feedstock most widely assessed [52-58]. Other feedstocks assessed for this region are agricultural residues, grass, switchgrass, wheat, and maize. The social aspect most often assessed in this region is "local employment". In general, over all the world regions considered, "local employment", "health", and "income" were found to be the social aspects more often assessed. The assessment of these aspects in quantitative terms is today more developed than for the others. In the case of "health of local community", for example, assessment using the indicator DALYs (Disability-Adjusted Life Years) has allowed its operationalization and introduction into LCAs. The least often assessed social aspects are "public commitment to sustainability issues" and "promoting social responsibility", which were assessed only in one pilot study in one European country. Case studies reported in the analyzed literature include production systems for trade and in a few cases for own consumption such as small-scale biogas.

\subsection{Social Aspects Assessed and/or Reported in the Literature of Biobased Value Chains According to Stakeholder}

The sheets define five main stakeholders to consider: workers, local community, consumers, society, and value chain actors.

\subsubsection{Stakeholder "Workers"}

In order to allocate the different social aspects to the impact subcategories proposed by the sheets, a more specific subdivision of the stakeholder group "workers" was adopted in this study. For example, this group could theoretically include smallholder farmers, since they work on their own farms. However, they hold land rights, make decisions, and take risks [59]. For this reason, they could be considered more similar to firms than company workers. A brief characterization of the stakeholder smallholder farmer in developing regions of the world is given in the following section.

\section{Smallholder Farmer Characterization}

As the focus of the review is on agricultural and forestry value chains, "smallholder farmers and family farms" are commonly considered the main stakeholders [32-34,37,38,48,50,51,60-63]. Smallholders and family farms are not always the same stakeholder. While smallholders are often associated with a limited size of the land they own, family farms are not related to a specific land size [64]. These two stakeholder groups frequently overlap, as smallholder farmers are often family farms, though not all family farms are considered smallholders. The specific characteristics for the definition of a smallholder have been a topic of debate for several years [65]. A characterization of the smallholder farmer based on the analyzed literature is included in this section to illustrate the overall profile of this stakeholder in developing countries (Table 3). The information contained in the table is derived from descriptions of smallholder farmers in developing regions found in the sources included in this review and does not aim to be representative at global level. The definition of smallholder is very heterogeneous and depends on the social conditions where the stakeholder resides.

The subdivision of stakeholder workers adopted in this study allocated the social aspects identified in the literature to three groups: "Smallholder farmers/Family farms", "Farm wage workers/Plantation workers/Forest workers", and "Mill workers/Biorefinery workers/Pre-chain company workers" (Table 4). The term "pre-chain company workers" refers to employees working in factories that produce inputs and materials to be used in the product system under analysis. For example, if the product system includes agricultural production, pre-chain company workers would include workers involved in fertilizer production. Table 4 gives a classification of the social aspects covered in the literature for the stakeholder "workers", which can also be found in the impact subcategories proposed in the sheets, and the stakeholder "smallholder farmer and family farm". The following paragraphs describe the aspects identified for this stakeholder from the articles collected. 
Table 2. Identified social aspects (positive or negative) assessed and/or reported in the literature according to biomass and world region.

\begin{tabular}{|c|c|c|c|c|c|c|c|c|c|c|c|c|c|c|c|c|}
\hline $\begin{array}{l}\text { Biomass/ } \\
\text { World Region }\end{array}$ & $\begin{array}{c}\text { Agr. } \\
\text { Residues }\end{array}$ & Cassava & Cotton & $\begin{array}{c}\text { Forest } \\
\text { Biomass }\end{array}$ & Grass & $\begin{array}{c}\text { Integrated } \\
\text { Systems }\end{array}$ & Jatropha & $\begin{array}{c}\text { Manure } \\
\text { and Biogas } \\
\text { Biomass }\end{array}$ & Oil Palm & $\begin{array}{c}\text { Roselle } \\
\text { and Trau }\end{array}$ & Rubber & Soybean & Sugarcane & Switch-Grass & Wheat and/or Maize & Ref. \\
\hline $\begin{array}{l}\text { Central and } \\
\text { Southern Asia }\end{array}$ & & & $\begin{array}{l}\text { HS, I, } \\
\text { AMR, } \\
\text { CB }\end{array}$ & & & Ix2, AMR & & $\begin{array}{l}\text { HS, I, EO, } \\
\text { TSx2 }\end{array}$ & & & & & & & & {$[32-37]$} \\
\hline $\begin{array}{l}\text { Eastern and } \\
\text { South Eastern } \\
\text { Asia }\end{array}$ & & $\mathrm{HS}, \mathrm{I}, \mathrm{LE}$ & & LE & & & & $\mathrm{HS}, \mathrm{TS}$ & $\begin{array}{l}\text { HSx2, CE, } \\
\text { LE, } \\
\text { AMRx2, } \\
\text { SHL }\end{array}$ & SHL & & & $\mathrm{HS}, \mathrm{I}, \mathrm{LE}$ & & & {$[38-43]$} \\
\hline $\begin{array}{l}\text { Europe and } \\
\text { Northern } \\
\text { America }\end{array}$ & SHL & & & $\begin{array}{l}\text { HS,Ix3, EO, } \\
\text { FA, H, CE, } \\
\text { RIR, LEx5, } \\
\text { PCS, PSR }\end{array}$ & LE, AMR & & & $\mathrm{CE}$ & & & & & & LE & $\mathrm{LE}, \mathrm{SR}$ & {$[52-58,63,66-70]$} \\
\hline Latin America & & & & & & $\mathrm{HS}, \mathrm{CB}$ & & & $\begin{array}{l}\text { HS, CL, } \\
\text { FA, D, } \\
\text { AMR }\end{array}$ & & & $\mathrm{I}, \mathrm{FL}, \mathrm{SR}, \mathrm{SI}$ & $\begin{array}{c}\text { Ix2, CL, } \\
\text { FLx2, EO, } \\
\text { CH, LEx2, } \\
\text { AMR, SI, SR }\end{array}$ & & & {$[44,45,47-49,61,62]$} \\
\hline $\begin{array}{l}\text { Sub-Saharan } \\
\text { Africa }\end{array}$ & & & & & & & $\begin{array}{l}\text { LE, } \\
\text { AMR }\end{array}$ & HS, EO & $\mathrm{D}, \mathrm{CE}$ & & $\mathrm{D}, \mathrm{CE}$ & & $\mathrm{I}, \mathrm{AMR}$ & & & {$[46,50,51,71]$} \\
\hline
\end{tabular}


Table 3. Characteristics of smallholder farmers in developing countries.

\begin{tabular}{|c|c|c|}
\hline Aspect & Characteristic & Reference \\
\hline Energy source & $\begin{array}{l}\text { No access to modern energy. Raw biomass, wood, cow dung, and } \\
\text { leaves used as fuel. Long distances to collect biomass reached on } \\
\text { foot. In some regions access to LPG. }\end{array}$ & [36] \\
\hline Illiteracy rate & $\begin{array}{l}\text { It varies according to the area under study (e.g., a survey in } \\
\text { Pakistan reported } 76 \% \text { illiteracy among respondents) }\end{array}$ & [34] \\
\hline Gender roles & Women's time is dedicated to domestic activities. & [36] \\
\hline Agricultural practices & $\begin{array}{l}\text { Cultivation using hand hoe or animal traction. Cultivation under } \\
\text { rainfed conditions. Low agricultural productivity. }\end{array}$ & {$[32,38]$} \\
\hline Land characteristics & $\begin{array}{l}\text { Land size, from less than } 2 \text { to } 2.6 \text { ha on average. Cultural, } \\
\text { religious, and spiritual value of land for the community. In } \\
\text { sub-Saharan African countries, customary ownership of land. }\end{array}$ & {$[34,50,60]$} \\
\hline Labor force & Family members are the main work force. & [61] \\
\hline
\end{tabular}

Table 4. Social aspects assessed and/or reported in the literature categorized according to the structure proposed by the Methodological Sheets for the stakeholder "workers" (subdivided by the authors into three groups).

\begin{tabular}{|c|c|c|c|}
\hline Social Aspect & $\begin{array}{l}\text { Smallholder Farmer/ } \\
\text { Family Farm }\end{array}$ & $\begin{array}{l}\text { Farm Wage Workers/ } \\
\text { Plantation Workers/ Forest } \\
\text { Workers }\end{array}$ & $\begin{array}{l}\text { Mill Workers/ } \\
\text { Biorefinery Workers/ } \\
\text { Pre-Chain Company Workers }\end{array}$ \\
\hline Health and safety & $\begin{array}{ll}\text { - } & \text { Fatal occupational } \\
\text { injuries [42] } \\
\text { - } & \text { Exposure to indoor air } \\
\text { pollution [36,38,51,71] } \\
\text { - } & \begin{array}{l}\text { Exposure to toxic } \\
\text { chemicals [32] }\end{array}\end{array}$ & $\begin{array}{l}\text { Plantation workers' } \\
\text { access to drinking } \\
\text { water [39] } \\
\text { - Accessibility to health } \\
\text { care and water [40] } \\
\text { - Provision of sanitation } \\
\text { facilities [40] } \\
\text { - Number of accidents and } \\
\text { occupational } \\
\text { diseases [49] }\end{array}$ & $\begin{array}{l}\text { - Fatal occupational } \\
\text { injuries [42] } \\
\text { - Occupational accidents and } \\
\text { diseases, toxicity [62] } \\
\text { - Occupational health } \\
\text { care [54] }\end{array}$ \\
\hline Fair salary & $\begin{array}{ll}\text { - } & \text { Income }[32-34,48] \\
\text { - } & \text { Money savings due to } \\
& \text { technology } \\
& \text { substitution [37] } \\
\end{array}$ & $\begin{array}{l}\text { - Wage }[42,44,56] \\
\text { - } \quad \text { Unfair wages [46] }\end{array}$ & - Wage $[42,54,56]$ \\
\hline Child labor & - Child labor $[45,49]$ & & - Young employees [54] \\
\hline Forced labor & - Forced labor [45] & - Slave labor [44] & \\
\hline Equal opportunities & $\begin{array}{l}\text { - Women's opportunity } \\
\text { cost [51] } \\
\text { - Access to education [36] }\end{array}$ & $\begin{array}{l}\text { Difference in the number } \\
\text { of male and female } \\
\text { employees [47] }\end{array}$ & $\begin{array}{l}\text { - Anti-discrimination } \\
\text { legislation [54] }\end{array}$ \\
\hline $\begin{array}{l}\text { Freedom of } \\
\text { association and } \\
\text { collective bargaining }\end{array}$ & & $\begin{array}{ll}\text { - } & \text { Collective rights [54] } \\
\text { - } & \text { Number of unionized } \\
& \text { employees [49] }\end{array}$ & \\
\hline Hours of work & & - Working time [54] & \\
\hline $\begin{array}{l}\text { Social security/ } \\
\text { social benefits }\end{array}$ & $\begin{array}{l}\text { - Capacity building, } \\
\text { training }[32,62]\end{array}$ & & \\
\hline
\end{tabular}

Health and Safety

The health and safety of smallholder farmers were assessed for a number of crops [32,42]. In cotton production, for example, interviews with farmers revealed that the application of toxic pesticides in traditional agriculture is associated with headaches, skin irritation, short-term blindness, and other symptoms [32].

An example associated with a positive impact on the health of household members-in relation to their previous health status-comes from the biogas value chain in rural areas of developing countries. It is estimated that, in 2016, approximately $40 \%$ of the world's population lacked access to clean 
fuels for cooking [72]. Many people in developing countries rely on biomass such as wood and dung as an energy source for cooking and also lighting. Exposure to smoke from the combustion of biomass can lead to respiratory diseases [71] and other symptoms including eye irritation [38]. Survey studies performed in Vietnam, Ethiopia, and Bangladesh report positive impacts from the installation of biogas digesters in smallholder farms and households $[36,38,51]$. The replacement of firewood by biogas digesters results in a reduction of indoor air pollution and thus decrease in health issues related to wood combustion [36]. In addition to the improvement in health, the household also saves in financial terms through decreased medical attention. Finally, a recurring example affecting the health of plantation workers was reported for palm oil production in Indonesia and Malaysia. Here, the plantation workers' access to drinking water was restricted due to pollution or limited availability $[39,40]$.

Fair Salary

"Fair salary" mainly refers to the value of a service being reflected in the wage received [19]. This aspect was mentioned only once in the reviewed literature [46]. Income and wages-but not if they are fair or not-were assessed mainly in the sugarcane-bioethanol value chain $[42,44,48]$. Low wages were reported in the cultivation of sugarcane in Brazil and Sierra Leone [46,48]. However, in a study performed in Thailand [42], wages reported for bioethanol production were higher than in a gasoline value chain. Some studies found monetary benefits for smallholder farmers resulting from changes in agricultural practices, like adopting agroforestry or changing to organic agriculture [32,34]. Others reviewed the economic aspects of implementing biogas plants in households [37].

\section{Child Labor and Forced Labor}

Child labor was assessed in only two studies, both in Latin America, in the palm oil, and sugarcane value chains $[45,49]$. However, no qualitative assessment using primary information on this aspect was found; the studies made use of secondary sources of information. For this reason, the stakeholder group for this aspect cannot be clearly identified from the reviewed literature. For example, it is not clear if child labor occurred from within the farmer's household or as wage workers on plantations. However, according to [73], more than two thirds of child labor involves children contributing to their families' livelihood.

Forced labor was reported in soybean and sugarcane cultivation in Brazil [44]. Here, again, the type of agricultural scheme where it takes place is unclear from the reviewed literature-within the smallholder household or more related to external and plantation workers.

\section{Equal Opportunities}

Equal opportunities according to gender is a social issue in both developing and developed countries. However, this aspect is much less often assessed than other aspects like "health and safety" and "wages". In developing countries, the role of women living in poor rural areas is usually confined to childcare and domestic activities [36]. This situation directly impedes their chances of gaining an education, acquiring a job and leaving the poverty cycle [36]. One aspect related to opportunities for women in rural areas is that of time saving, especially in own consumption production systems. Various authors reported that women benefit from time saved on household activities through the replacement of wood by biogas. A survey performed in a rural community in Bangladesh reported that women benefit by saving on average $1 \mathrm{~h}$ and $43 \mathrm{~min}$ ' household work, specifically cooking, cleaning and collecting fuel wood, after taking into account the time spent in animal husbandry and water collection to feed the digester [36]. Studies performed in Ethiopia and Vietnam also mentioned anticipated time savings [38,51]. A study in Nepal [35] found that the introduction of biogas led to women spending less time in wood or dung collection for combustion; however, they did not find significant evidence for a decrease in time spent on cooking. The time saved could be allocated to agricultural activities [35], work, or leisure [38] or to the education of women and children, thus contributing to the region's 
development by, for example, improving the literacy rate [36]. The contribution of biogas to long-term development could be facilitated by making complementary opportunities available [35], for instance educational programs or institutions for people who wish to allocate their time to this activity [35].

\section{Social Benefits}

Capacity building was mentioned in two case studies that assessed the change from traditional agricultural practices to new practices. For example, implementation of organic farming is knowledge-intensive and requires training. Farmers profit from trainings and from the creation of platforms for exchanging knowledge [32]. Another example comes from the comparison of conventional with integrated systems, such as crop-livestock-forest systems. Highly integrated systems for food and wood production show positive impacts at the farm level, mainly through increased professional training and higher investment in research and development [62].

\section{Other Aspects}

"Freedom of association and collective bargaining" and "hours of work" were the least assessed aspects.

\subsubsection{Stakeholder "Local Community"}

This section briefly describes those aspects identified in the literature for the stakeholder "local community". The results from this study show that the "smallholder farmer and family farm"-although not mentioned in the sheets-is a relevant stakeholder group that overlaps with the stakeholder "local community". However, they are not always the same stakeholder, for example in an urban setting local community differs from farmers. Therefore, it was deemed necessary to include the stakeholder "smallholder and family farm" in Table 5, next to the stakeholder "local community".

Table 5. Social aspects assessed and/or reported in the literature categorized according to the structure proposed by the Methodological Sheets for the stakeholder "local community" and the here proposed stakeholder "smallholder and family farm".

\begin{tabular}{|c|c|}
\hline Social Aspect & Smallholder and Family Farm and/or Local Community \\
\hline Delocalization and migration & $\begin{array}{ll}- & \text { Land grabbing and displacement [50] } \\
\text { - } & \text { Population displaced by violence [49] } \\
\end{array}$ \\
\hline Cultural heritage & - $\quad$ Transformation of rural homes and landscape due to land use change [48] \\
\hline Community engagement & $\begin{array}{ll}\text { - } & \text { Community involvement in decision-making [40,50] } \\
\text { - } & \text { Sharing of information with local community [40] } \\
\text { - } & \text { Local community engagement [54] }\end{array}$ \\
\hline Respect of indigenous rights & - $\quad$ Land rights, energy sovereignty of indigenous peoples [53] \\
\hline Local employment & - Job creation, employment $[40,42,43,47,48,54-57,67,68,74,75]$ \\
\hline Access to immaterial resources & - $\quad$ Biopiracy [76] \\
\hline Access to material resources & $\begin{array}{ll}\text { - } & \text { Access to land }[34,46,75] \\
\text { - } & \text { Access to food }[34,46,48,75] \\
\text { - } & \text { Food availability risk }[32,48] \\
\text { - } & \text { Food supply [49] } \\
\text { - } & \text { Food security impacts through imports [67] } \\
\text { - } & \text { Food price inflation }[77] \\
\text { - } & \text { Access to seeds }[32] \\
\text { - } & \text { Land tenure concentration [48] } \\
\text { - } & \text { Loss of autonomy and control over land through land leasing [48] } \\
\text { - } & \text { Access to water, water rights [39] }\end{array}$ \\
\hline $\begin{array}{l}\text { Safe and healthy living } \\
\text { conditions }\end{array}$ & $\begin{array}{ll}\text { - } & \text { Odor and pollution [40] } \\
\text { - } & \text { Human health, exposure to pollutants }[41,66,69]\end{array}$ \\
\hline
\end{tabular}




\section{Delocalization and Migration}

According to the IFC Guidance Note 5 on Land Acquisition and Involuntary Resettlement [78], displacement can be physical, if it implies the loss of shelter; or economic, if it affects the livelihoods of people due to restricted access, for example, to land. Physical displacement was reported in the analyzed literature in the cultivation of oil palm and rubber, as well as food and feed in sub-Saharan Africa [50] and oil palm in Latin America [49]. The risk of economic displacement was reported in sugarcane cultivation also in sub-Saharan Africa [46]. According to [79], considerable displacement of people has taken place mainly in African countries due to large agricultural projects. Displacement of people is often related to land rights issues, some of which are described in the "access to material resources" subsection below.

\section{Community Engagement}

Organizations' decisions can affect communities in manifold ways and therefore organizations should engage actively with community members to understand their concerns and respond to them [19]. An example of lack of community engagement is given in the context of land grabbing in African countries. Governments and private investors make decisions to buy or lease the lands of smallholders for large-scale crop production with low or no engagement of the communities [50]. Furthermore, the compensation given to smallholders in the form of low-wage employment is not always perceived as adequate by those affected. Community engagement is, however, not only an issue in developing countries. This aspect was also mentioned in a case study in Italy, emphasizing the role of the local government in securing a sustainable transition to the bioeconomy [52].

\section{Respect of Indigenous Rights}

It is estimated that over $25 \%$ of the world's land surface is managed or owned by indigenous populations [80]. Indigenous peoples living in remote areas around the world are battling to secure their rights with respect to resources such as food and land [53]. This aspect can be illustrated by an example from Alaska. Between 1970 and 1980, natives lost a proportion of their lands, partly due to the development of the oil and gas industry [53,81]. Today, oil and gas constitute one of the largest industries in Alaska. Nevertheless, fossil diesel prices are twice as high as in other U.S. states. For this reason, there is a motivation among community members to replace fossil diesel and kerosene with combustion of local woody biomass, like cottonwood, as a sustainable alternative for heating purposes. This may transfer energy sovereignty to the community, whose people are feeling the effects of climate change in a stronger way due to their location [53]. According to [53], energy sovereignty is of high importance for native people in these regions, particularly because they have fought for decades to preserve their rights to resources which were taken away from them at various opportunities.

\section{Local Employment}

Job creation was the most often assessed aspect of all. It was mainly addressed in the cultivation stage of forest biomass $[55,58]$ and sugarcane $[42,48]$ value chains, and in conversion plants $[56,68,74]$. Some examples of this aspect identified in the literature are given below.

In the sugarcane value chain, interviewees in a study performed in Brazil stated that job creation was the main advantage of cultivating the crop, and said it was interesting to move from annual crops to sugarcane if there was not enough on-farm labor or if prices for annual crops are low [48]. A study in Thailand found that bioethanol from sugarcane and cassava would create more jobs than gasoline production [42]. It was estimated that cassava cultivation accounts for $56 \%$ of total employment generated in the production of bioethanol from cassava, while sugarcane cultivation accounts for $72 \%$ of total employment in ethanol production from sugarcane molasses, indicating that most jobs are created in the agricultural stage [42]. This may be partly explained by the manual and less mechanized agricultural practices common in developing countries, which require more human 
labor [42]. These jobs are usually performed on a daily or seasonal basis and are considered low-skilled work [42].

In the forestry sector, a higher utilization of biomass could impact local employment positively. In Lithuania, for example, an increase in wood demand would lead to a 10 to $38 \%$ increase in jobs by the year 2100 compared to the reference year 2015 [55]. Furthermore, sparsely populated regions facing declining employment, high rates of unemployment, and outmigration could also benefit from local biomass projects [57]. For instance, in a region of Finland, the production of biochar from forestry biomass can contribute to the regional development by creating jobs and providing higher incomes for local people. This could also help reduce the depopulation of the region [57].

Although job creation is expected in most cases, negative social impacts arising from the failure of conversion plants were also cited in the literature. For example, an analysis of two case studies performed in southern U.S. [58] reported that the bankruptcy of one plant using yellow pine as feedstock had a negative influence on the community, since local expectations had been raised during construction of the plant. In the other case study, the level of forecasted employment was not reached, since the plant was never run at full capacity.

\section{Access to Immaterial Resources}

Biopiracy refers to the disregard, mainly by profit-oriented organizations or companies, of the knowledge and intellectual property that indigenous peoples and local communities around the world have on biological resources [82]. To counteract potential negative impacts arising from biopiracy, the Nagoya protocol came into force in 2014. It regulates the use of and sharing of benefits share from genetic resources around the world [76]. Legal measures regarding biopiracy in mega- and highly diverse regions of the world, such as Australia and Brazil, were explored by [76].

\section{Access to Material Resources}

According to the sheets, access to material resources covers the access to natural (water, land, food) and man-made resources (infrastructure) [19,83].

Access to water, land, and seeds. Access to water can be hindered by affecting water quantity or water quality [44]. The level of water use intensity can be related to a potential restriction to access to water in a local community-for example, a water intensity assessment of processes involved in the production of biodiesel from soybeans in Brazil compared the amount of water required for two transesterification agents, one fossil-based and one bio-based [44]. Access to water can also be threatened by water pollution $[39,50]$. This was reported, for example, in Indonesia where pesticides, herbicides, fertilizers, and POME (palm oil mill effluent) from the production of palm oil were polluting water bodies [39].

Issues of access to land were reported in regions with unclear land rights and mainly where large-scale agricultural projects had been started. Examples include Sierra Leone, where a number of informal communal tenure forms exist [46], and Tanzania, where land in communal ownership was transferred to the government to be leased out for jatropha plantations [75]. At times, governments make deals directly with foreign investors with a low rate of prior consultation of the people affected. For instance, a case study in Nigeria found that investors leased or bought part or all of the smallholders' land for large-scale agricultural production with a prior consultation rate of only $24 \%$ [50].

In some cases, access to land becomes an issue when a company producing biomass on a large-scale fails, and it is not clear if the lands are to be returned to the local community $[75,84]$. In other cases, such as the sugarcane value chain, the acquisition of "marginal lands" by foreign investors interferes with the community members' access to land, since the so-called "marginal lands" are not always marginal or unused. They are fallow lands relevant to poor or "marginal" people who rely on them for firewood collection, medicinal plants, and for their livelihoods in general [46]. In this sense, out-grower business models are considered less aggressive to local communities, since, in these schemes, land rights are not transferred to investors and landholders work their own lands [75]. 
Another aspect related to land is inequality in land tenure. This was assessed by [49] for palm oil production in Colombia. According to [49], the high concentration of land in a small number of hands is associated with violence and poverty. One of the findings of the study was that land concentration is likely to increase with the expansion of plantations.

Another issue related to access to material resources, recorded in the study of [32], is access to seeds. Interviewed farmers reported a lack of seed banks in some regions of India, making them dependent on-often distant-markets, where seeds available for food cultivation are of low quality. In addition, in India, the suicide committed by thousands of small-scale farmers due to financial pressure has been controversially associated with the monopolization of GM seeds [85] for the cultivation of Bt cotton. Furthermore, access to organic cotton seeds can be hindered, for example, by contamination of non-GM seeds [86].

Food security. According to the FAO, food security has four dimensions: food availability, access to food, food stability, and food utilization. Food availability is related to food supply, either from domestic production or imported [87]. It can be affected, for example, if the inputs for food production are re-allocated to fuel production [75]. Access to food, by contrast, does not refer to supply, but to the economical or physical access to food. For instance, a rise in food prices may hinder the access of poor people to food [75]. Food stability refers to the continuous or interrupted supply or access to food due to economic or environmental shocks [87]. An example is land use change from food to energy crops [75]. Finally, food utilization refers to the nutritional content of food, which can vary according to consumption patterns [75]. Food security is not explicitly included in the sheets. However, the aspect "access to food" corresponds to the impact subcategory "access to material resources" together with land rights, as explained by [83]. In the literature reviewed, access to food was mainly mentioned in case studies performed in developing countries, including India [32], Colombia [49], and countries of sub-Saharan Africa $[46,75]$. Food security, by contrast, was addressed in Europe, where the indicator was "Food security: net imports" [67], relating the issue to food produced abroad.

One survey carried out with jatropha plantation workers revealed that they considered their work positive for food security because they received an income that enabled them to buy food [75]. Another study performed in a large-scale sugarcane production project in Sierra Leone found that the project was not beneficial to all community members. Some of them reported losing their access to land due to the project but were not employed by the company, raising their concerns with respect to access to food [46]. Various authors identified the plantation model as being related to food insecurity. This is particularly the case when agricultural projects fail without an alternative plan, as they stop providing employment and at the same time lands may not be returned to the local community [75]. In the palm oil value chain for biodiesel production, competition with the food industry was illustrated by [77]. A rise in the demand for palm oil caused by the biodiesel industry may have led to a shortage in the supply of oil for food consumption, leading to an increase in the price of palm oil. Food inflation can occur if competition for land between crops is created by higher incentives being given to certain crops. This can lead to an increase in land demand and, in turn, land prices in order to meet the crop demand, and thus a rise in food production costs $[77,88]$. In the biobased materials sector, farmers interviewed in Odisha, India mentioned that organic cotton farming had positive effects on food security because it encourages food crop cultivation, for example intercropping, thus increasing food availability [32].

\section{Safe and Healthy Living Conditions}

Industrial activities can affect the health of the local community where they are carried out. One example of this is given for the production of crude palm oil, which generates a wastewater stream called palm oil mill effluent (POME). In addition to methane, this effluent releases a strong odor into the surrounding neighborhood. According to [40], this was reflected in the number of complaints that governmental institutions in Malaysia receive each year due to odor pollution stemming from crude palm oil production facilities. 
The impacts on human health derived from various pollutants emitted in the production of biobased products were also assessed. Ref. [66] analyzed the production and consumption of raspberries that use biobased plastics as packaging. Results indicate that the greatest impact on human health were due to emissions derived from refrigeration and car transport during the sales and consumption stages of the value chain.

Other studies model impacts on human health using the LCA tool. One example of this is the study performed by [41] on the production of biodiesel for use in cruise ships from two potential feedstocks: roselle (Hibiscus sabdariffa L.) and trau (Vernicia montana L.). In that study, the potential impact on human health was assessed using DALYs. It was found that, under the conditions analyzed, the biodiesel system had lower impacts on human health than fossil diesel. The main contributors to human health impacts were seed extraction and fuel combustion.

\subsubsection{Stakeholders "Society", "Consumer", and "Value Chain Actors"}

Table 6 lists the aspects identified for the stakeholders "society", "consumer" and "value chain actors". As can be seen, only a few subcategories of these stakeholders were found in the reviewed literature.

\section{Supplier Relationships and Production Schemes}

From Table 6, the aspect "supplier relationships" is addressed by various authors. In the work of [70], various aspects related to the relationship between biorefineries and farmers were examined. These aspects are forms of collaboration between the company and farmer cooperatives, the conditions of the contract (duration, flexibility), price policy, assistance of farmers (trainings, financial support), and others. The relationship of companies with their suppliers could be partly determined by the production scheme or business model. Feedstock production and its further conversion into bioproducts can follow a variety of business models. For instance, six different production models were identified by [89] in biofuel value chains in southern Africa. These models vary in their production aim, which can be either for the producer's own fuel consumption or for trade. Production models for trade include out-grower schemes, independent producers, and corporate plantations. The first group refers to smallholder farmers, who provide feedstock, often grown on their own land, to corporate processing facilities. This scheme is also called 'contract farming', since there is a contractual relationship between the producer and the processing facility with a fixed price being established.

Table 6. Social aspects assessed and/or reported in the literature categorized according to the structure proposed by the UNEP/SETAC in the Methodological Sheets for Subcategories in S-LCA for the stakeholders "society", "consumer" and "value chain actors".

\begin{tabular}{llll}
\hline Stakeholder & $\begin{array}{l}\text { Social Aspect from } \\
\text { the Sheets }\end{array}$ & \multicolumn{2}{l}{ Social Aspects from the Literature } \\
\hline Society & $\begin{array}{l}\text { Public commitment to } \\
\text { sustainability issues }\end{array}$ & $\bullet$ & $\begin{array}{l}\text { Corporate sustainability and } \\
\text { responsibility reporting, code of } \\
\text { conduct [54] }\end{array}$ \\
\hline Consumer & End-of-life responsibility & $\bullet$ & Biobased plastic biodegradability [90] \\
\hline Value chain actors & Suppliers relationships & - & $\begin{array}{l}\text { Land renting contract [48] } \\
\text { Contract flexibility, price policy [70] } \\
\text { Relationship between biodiesel plants } \\
\text { and family farming cooperatives [61] }\end{array}$ \\
\hline & $\begin{array}{l}\text { Promoting social } \\
\text { responsibility }\end{array}$ & - & $\begin{array}{l}\text { Practices of suppliers, contractors, } \\
\text { sub-suppliers, sub-contractors [54] }\end{array}$ \\
\hline
\end{tabular}

Although this model has been reported to potentially contribute to poverty alleviation and be inclusive for smallholder farmers, the contract design is crucial for the success of the contractual arrangement [91]. Independent commercial farmers follow a similar scheme, but there is no contractual 
relationship between the facility and the producers. This scheme is frequent in European countries [89]. Finally, corporate plantations refer to a model in which vast amounts of land are purchased or leased by a corporate mill [89] for the large-scale cultivation of a single crop, with an entirely hired labor force [92]. This last model has been associated with displacement of local communities and land grabbing [89].

\subsection{Overlooked Aspects}

This section briefly explains those aspects identified that are not included in the sheets. These mainly belong to the stakeholder "smallholder farmers and family farm" (Table 7).

Table 7. Social aspects identified in the literature which are not present in the Methodological Sheets for Subcategories in S-LCA.

\begin{tabular}{l}
\hline Social Aspect \\
\hline $\begin{array}{l}\text { Smallholder inclusiveness in the markets } \\
\text { - } \quad \text { Social inclusion/exclusion of small producers } \\
\quad \text { from the market }[48,61]\end{array}$ \\
\hline Time saving \\
- $\quad$ Time saving for women $[35,36,38]$ \\
\hline
\end{tabular}

\subsubsection{Inclusion of Smallholder and Family Farms into the Market}

The aspect of social inclusion/exclusion of smallholder farmers was assessed in two case studies, one on sugarcane and the other on soybean production, both in Brazil. An example of exclusion of smallholders is given by [48]. In sugarcane production in one region of Brazil, the minimum size required by sugar mills to offer lease contracts to farmers was 70 ha. When sugarcane production expanded, landowners with this amount were able to rent out part of their land and obtain monetary benefits. On the other hand, the leasing of land with a size of less than 70 ha was not profitable either for small farmers or for sugar mills. Thus, small producers engaged in annual crops rather than sugarcane received lower overall incomes than large-scale farmers, also because annual crops became less profitable after the sugarcane expansion. This situation led to the concentration of land in the hands of a few to the exclusion of smallholders.

An example of smallholder inclusion also comes from Brazil. As part of the national biodiesel policy, the Brazilian government created the certification "Social Fuel Seal" to tackle social sustainability and include family farming in the soybean biodiesel production chain [61]. Under this certification scheme, biodiesel plants buy raw materials from family farmers, who in turn receive technical support from the plants. The biodiesel plants are allowed to pay lower taxes and have the right to sell all the biodiesel produced through government auctions.

\subsubsection{Other Aspects}

The sheets propose the subcategory "equal opportunities", which includes gender equality. The aspect "time saving for women" could fit into such subcategory. This aspect was already described in the biogas value chain in Section 3.2.1.

"Social acceptance" also plays a relevant role in the transition to renewable energies. For example, in Germany, there are to date more than 50 "bioenergy villages". Their existence has been mainly driven by local communities and civil society. However, the further development of renewable energies to satisfy a proportion of local demand for electricity and heat has been facing opposition from several community members throughout the country [93]. This opposition is said to be driven by diverse factors including the increase in traffic in villages and the fear of increasing property prices due to the new projects [93]. Another example of social acceptance is given in a study in Scotland [63], where it was found that farmers involved in livestock production and arable cropping were reluctant 
to cultivate short rotation coppice (SRC) for bioenergy production for various reasons including the socio-cultural identity of farmers and their preference for food cultivation. However, social acceptance is an issue present at various stages in the value chain. For instance, palm oil-based biodiesel has been criticized for its impacts on the environment and competition with food production and the biodiesel product itself has, in some cases, been rejected by car manufacturers due to its potential damage to engines [77].

\section{Discussion}

The relevance of social aspects is determined by contextual factors and the characteristics of stakeholders involved in a given place; therefore, these are context dependent. This study identified recurrent social aspects in agricultural and forestry-based value chains in different world regions and production systems. The analysis of empirical case studies and review articles aimed to contribute to the development of S-LCA in the context of the bioeconomy. The most recurring social aspects identified in the analyzed literature are local employment, income, health, equal opportunities for women, community engagement, land-related issues, and food security. As reported by [14], these mainly bottom-up findings confirm the social aspects commonly suggested in various top-down frameworks for the assessment of the biobased economy, including health and safety, social acceptability, food security, income, employment, land concerns, worker-related concerns, energy security, profitability, and gender issues.

\subsection{Recurring and Overlooked Aspects}

Local employment was the most frequently assessed social aspect due to its socio-economic relevance and the existence of methods for the quantitative estimation of the number of jobs created. However, a deeper analysis of the quality of jobs created should also be included, for example in terms of required skills level, income level, potential contract conditions, and potential risks associated with the nature of the jobs. In addition, short-term jobs created strictly for biomass extraction or for construction of facilities may have limited positive impacts in comparison to longer-term jobs, for instance local biomass processing activities, which may offer employees stability and foster their professional development. Therefore, a deeper analysis of the aspect "local employment" is needed to provide information beyond quantitative values, allowing a clearer understanding of the extent of the social impact.

With respect to the aspect "equal opportunities according to gender", bottom-up assessments highlight the relevance of women's role and lack of opportunities (for example, due to the time they allocate to household activities) in rural areas of developing regions of the world. Thus far, an indicator commonly used in S-LCA for this aspect is the gender wage gap. Given that a large proportion of women in rural areas of developing countries do not have a job and thus a wage, the suitability of this indicator is limited. Therefore, when assessing equal opportunity aspects of agriculture-based value chains, it is also necessary to consider how women who dedicate their time to household activities are affected by the value chain. This can be seen, for instance, in small-scale biogas production systems which enable women in rural areas to have more time during the day to perform other activities, such as participating in educational programs, where available.

Land-related issues and displacement driven by agricultural projects appear to be predominant mainly in countries of sub-Saharan Africa and Latin America, where this aspect was reported most in the literature reviewed. However, land grabbing issues have often been reported in other regions including Asia [94]. In the study of [95], evidence of land grabbing was even collected in a number of European countries. This reveals the need for the individual selection of social aspects for specific case studies, since a generalized selection approach can lead to the omission of relevant social aspects-in this case, land grabbing in certain European countries. Some sources suggest that the business model (e.g., out-grower model versus plantation) under which the feedstock is cultivated may indicate certain patterns of social issues [96]. For instance, land-related issues appear to be related to the scale of 
the project and the business model, with land issues mainly being reported in large-scale projects and plantation schemes. Corporate plantations are described as the typical model for example for sugarcane and soy production in Brazil and oil palm in Malaysia and were related to displacement issues, since thousands of hectares of land were often purchased by the processing company involved. Therefore, the scale and the production scheme need to be analyzed when assessing the social performance of biobased value chains of agricultural and forestry origin. Identifying the business model may be a starting point to help understand how the land ownership and food security of local communities and farmers can be affected in the value chain.

Aspects overlooked in the sheets are "inclusiveness of smallholders in the markets" and "social acceptance". Inclusiveness of smallholders in value chains has the potential to offer livelihood alternatives to rural people, thus it is of particular relevance in a sustainable transition to the bioeconomy. Smallholders' ability to enter markets is often limited by a range of factors including land size. These structural barriers can lead to social and economic exclusion. One approach to introducing this aspect into S-LCA could be the assessment of the land tenure structure of a given rural region by means of a land concentration indicator, which would provide information on the land tenure structure in a specific region and give an idea of the potential social impacts associated with it. This analysis could also provide an insight into the compatibility of a business model in the region of analysis (e.g., plantation or out-grower scheme) with the land tenure profile.

\section{2. "Farmers": The Main Stakeholder in the Biomass Production Stage}

The regional differentiation of stakeholder identification in the reviewed literature reveals a clear focus on the "smallholder farmer" and the "family farm" in the case studies of Asian, African, and Latin American regions. By contrast, in Northern American and European countries, the case studies are predominantly focused on "local communities" as a general category associated with job creation, without referring directly to "smallholders and family farms". This could be associated, among other factors, with a higher coverage of sustainability dimensions in the assessments performed in Northern America and Europe reviewed in this literature. Most of these studies are triple bottom line sustainability assessments that do not focus only on the social aspects but also analyze economic and environmental factors. This leads to a reduced number of stakeholders covered and limits the studies to quantitatively measurable aspects such as employment and potential impacts on health.

While the focus was on finding relevant social aspects and not stakeholders, the review clearly identified that the stakeholders "smallholder and family farms" should be addressed in biobased value chains. This led to the need for further differentiation of the stakeholder "worker" and consideration of social aspects belonging to the stakeholder "local community" for a complete allocation of aspects addressed in the literature for "smallholders and family farms". The stakeholder "smallholder and family farm" is not considered in the Methodological Sheets for subcategories in S-LCA; however, its inclusion in the assessment of biobased value chains with agricultural and forestry origin, especially when assessing the biomass production stage, is of high relevance. It is estimated that there are approximately 570 million farms worldwide [64]. In addition, 475 million of these farms are less than 2 ha in size and are responsible for the operation of $12 \%$ of agricultural land globally [64]. On the other hand, $75 \%$ of the world's agricultural land is operated by family farms, irrespective of their land size. It is estimated that there are more than 500 million family farms worldwide, with family farms and smallholders being overlapping groups [64]. This implies that production of agricultural and forestry-based products is highly dependent on family farms and smallholders. Therefore, when assessing a biobased value chain, the "smallholder and family farm" is a main stakeholder and should not be neglected. Against this background, many products with agricultural or forestry origin are likely to directly affect a smallholder or family farm because they manage most of the land. In addition, jobs in agriculture account for $40 \%$ of the world's human labor force, representing the largest global employer [97]. Moreover, "smallholders and family farms" in general have been undergoing difficult periods, for example due to climate change. In this setting of vulnerability, it is even more relevant to emphasize and include "smallholders and family farms" in the 
assessment of biobased value chains. The inclusion of "smallholders and family farms" in the assessment of biobased value chains is in line with previous studies and is not novel; however, its relevance is worth emphasizing. For instance, in the most recent version of Product Social Impact Assessment (PSIA), "small entrepreneurs" were proposed as an affected stakeholder. In addition, Ref. [98] stated that "farmers", and not only "smallholders", should be considered in the S-LCA of food chains. Some case studies also include this stakeholder. For example, Ref. [99] added "farmers" as a further stakeholder separate to the stakeholder "workers", and [100] included "farm owners". Even if social aspects of the suggested stakeholder "smallholder and family farms" partially overlap with those of the stakeholder "workers" and "local community", a specific definition of this stakeholder and related social aspects is required.

Figure 2 shows social aspects and indicators that were compiled from this study and that are recommended for the assessment of the stakeholder "smallholder and family farm". This approach does not aim to be comprehensive or to offer direct quantifiable indicators; however, it represents a starting point for the inclusion of the previously mentioned stakeholder in S-LCA. In addition, a contextual analysis will always be required prior to the selection of specific indicators to be applied in a study.
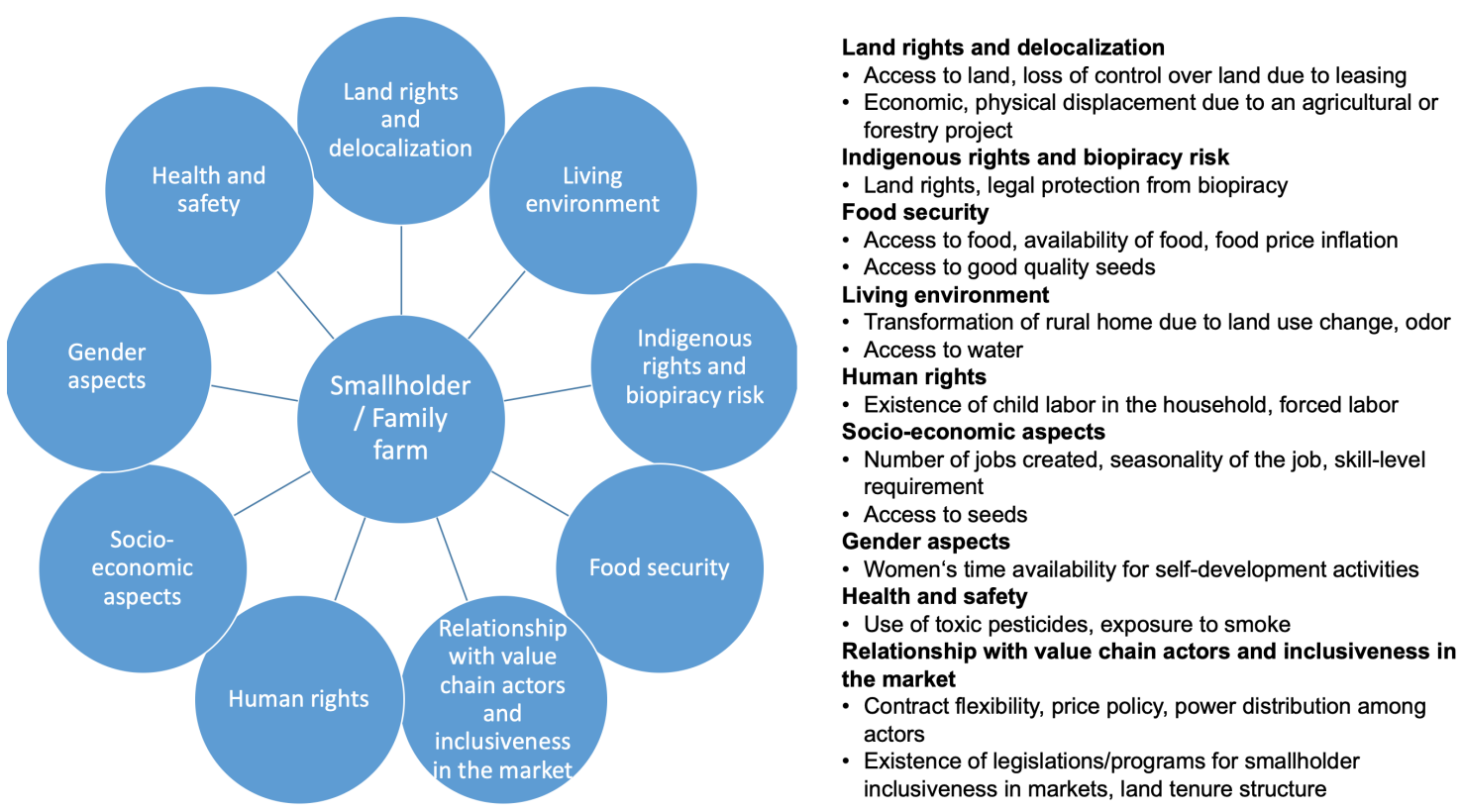

Figure 2. Recommended social aspects and indicators to cover when assessing "smallholders and family farms" (own elaboration).

Aspects covered in the sheets, though not widely addressed in the analyzed literature, might be of high importance in agricultural and forestry settings. These include migrant workers in agriculture, cultural heritage, and aspects recently proposed by the revised guidelines for S-LCA, such as poverty alleviation and animal welfare.

Given the breadth of social aspects and the wide range of subtopics covered in the literature, this review can only be considered representative to a certain extent. It provides a general overview of recurring social aspects in empirical assessments of agricultural and forestry-based value chains in different regions of the world. Furthermore, the search could be extended to other databases such as Google Scholar and Web of Science to increase the coverage of available literature.

\section{Conclusions and Outlook}

This study reviewed a selected and recent body of peer-reviewed literature on social aspects reported or assessed in case studies in land-based production systems of the bioeconomy using the Methodological Sheets for subcategories in S-LCA as a reference. The recurring aspects were found 
to be local employment, income, health, equal opportunities for women, community engagement, land-related issues, and food security. By contrast, child labor, forced labor, indigenous rights, cultural heritage, access to immaterial resources, freedom of association, and supplier relationships were found to receive less attention. A number of other aspects, in particular those affecting the stakeholders "consumer" and "society" such as corruption, did not appear at all in the reviewed literature. It can be concluded that the Methodological Sheets for Subcategories in S-LCA provide a good coverage of the aspects addressed in case studies of land-based production systems. In addition, the present study clearly illustrates that the stakeholder "smallholders and family farms" was widely addressed in empirical literature, though not explicitly indicated in the Methodological Sheets for subcategories in S-LCA. This stakeholder needs to be addressed when assessing agricultural and forestry-based value chains, especially at the biomass production stage. In practice, this study provides a set of social aspects to be considered when addressing the stakeholder "smallholder/family farm". Aspects considered for the assessment of this stakeholder could include: land rights and delocalization, indigenous rights, biopiracy risk, food concerns, human rights violations, gender equality in the household, transformation of the landscape, health, socio-economic aspects, inclusiveness of smallholders in the markets, and contractual relationships with other stakeholders. The operationalization of indicators for the stakeholder "smallholder/family farm" is beyond the scope of this study; however, further work is required to further elaborate the suggested stakeholder, social aspects, and indicators in case studies of agricultural and forestry-based value chains. A comparison of the indicators proposed here with existing frameworks (e.g., GBEP, RSB, and SAFA) could be a starting point for future work.

Theoretically, this study reveals the importance of also examining information collected and analyzed by empirical literature outside S-LCA for the improvement of the S-LCA framework.

Author Contributions: Conceptualization, N.A.M.V., M.W., and I.L.; researching and writing, N.A.M.V. with contributions from R.V.-C. (Discussion section), J.L. and I.L. All authors have read and agreed to the published version of the manuscript.

Funding: This work was supported by grants from the Ministry of Science, Research, and the Arts of Baden-Wuerttemberg (funding code 7533-10-5-188A).

Acknowledgments: The authors thank Nicole Gaudet for the proofreading of the manuscript.

Conflicts of Interest: The authors declare no conflict of interest. The funders had no role in the design of the study; in the collection, analyses, or interpretation of data; in the writing of the manuscript, or in the decision to publish the results.

\section{Abbreviations}

The following abbreviations are used in this manuscript:

DALY Disability-Adjusted Life Years

IFC International Finance Corporation

ILO International Labour Organization

LCA Life-Cycle Assessment

S-LCA Social Life-Cycle Assessment 


\section{Appendix A}

Appendix A.1

Table A1. Articles included in the analysis.

\begin{tabular}{|c|c|}
\hline Author, Year & Article \\
\hline Altenbuchner et al., 2018 & $\begin{array}{l}\text { Social, economic and environmental impacts of organic cotton production on } \\
\text { the livelihood of smallholder farmers in Odisha, India }\end{array}$ \\
\hline $\begin{array}{l}\text { Annuar \& Abdullah } \\
\text { et al., } 2016\end{array}$ & $\begin{array}{l}\text { Challenges in biodiesel industry with regards to feedstock, environmental, } \\
\text { social and sustainability issues: A critical review }\end{array}$ \\
\hline Augustine et al., 2016 & $\begin{array}{l}\text { Economic and social issues related to foreign land grab and capacity building in } \\
\text { Zambian Agricultural economy }\end{array}$ \\
\hline Barros Ribeiro et al., 2018 & $\begin{array}{l}\text { Biodiesel and social inclusion: An analysis of institutional pressures between } \\
\text { biodiesel plants and family farmers in southern Brazil }\end{array}$ \\
\hline Bautista et al., 2019 & $\begin{array}{l}\text { A system dynamics approach for sustainability assessment of biodiesel } \\
\text { production in Colombia. Baseline simulation }\end{array}$ \\
\hline Bentzen et al., 2018 & $\begin{array}{l}\text { A social cost-benefit analysis of biogas technologies using rice straw and water } \\
\text { hyacinths as feedstock }\end{array}$ \\
\hline Blanc et al., 2019 & $\begin{array}{l}\text { Use of bio-based plastics in the fruit supply chain: An integrated approach to } \\
\text { assess environmental, economic, and social sustainability }\end{array}$ \\
\hline Bohra et al., 2018 & $\begin{array}{l}\text { Socio-economic impact of Biofuel Agroforestry Systems on Smallholder and } \\
\text { Large-holder Farmers in Karnataka, India }\end{array}$ \\
\hline Brewer et al., 2018 & Towards energy sovereignty: Biomass as sustainability in interior Alaska \\
\hline Cavicchi et al., 2017 & $\begin{array}{l}\text { The influence of local governance: Effects on the sustainability of } \\
\text { bioenergy innovation }\end{array}$ \\
\hline Cong et al., 2017 & $\begin{array}{l}\text { Where to implement local biotech innovations? A framework for multi-scale } \\
\text { socio-economic and environmental impact assessment of Green Bio-Refineries }\end{array}$ \\
\hline Costa et al., 2018 & $\begin{array}{l}\text { A socio-eco-efficiency analysis of integrated and non-integrated } \\
\text { crop-livestock-forestry systems in the Brazilian Cerrado based on LCA }\end{array}$ \\
\hline Gabisa \& Gheewala, 2019 & $\begin{array}{l}\text { Potential, environmental, and socio-economic assessment of biogas production } \\
\text { in Ethiopia: The case of Amhara regional state }\end{array}$ \\
\hline Heider et al., 2019 & $\begin{array}{l}\text { Plastics of the future? The impact of biodegradable polymers on the } \\
\text { environment and the society }\end{array}$ \\
\hline Heidari et al., 2019 & A Sustainable Power Supply System, Iran's Opportunities via Bioenergy \\
\hline Horn et al., 2018 & $\begin{array}{l}\text { Bio-inspired sustainability assessment for building product development - } \\
\text { Concept and case study }\end{array}$ \\
\hline Husgafvel et al., 2017 & $\begin{array}{l}\text { Development and piloting of sustainability assessment metrics for arctic process } \\
\text { industry in Finland-The biorefinery investment and slag processing } \\
\text { service cases }\end{array}$ \\
\hline Interlenghi et al., 2017 & $\begin{array}{l}\text { Social and environmental impacts of replacing transesterification agent in } \\
\text { soybean biodiesel production: Multi-criteria and principal component analyses }\end{array}$ \\
\hline Jasinevičius et al., 2017 & $\begin{array}{l}\text { Assessing impacts of wood utilisation scenarios for a Lithuanian bioeconomy: } \\
\text { Impacts on carbon in forests and harvested wood products and on the } \\
\text { socio-economic performance of the forest-based sector }\end{array}$ \\
\hline Jin et al., 2019 & $\begin{array}{l}\text { Integrated sustainability assessment for a bioenergy system: A system dynamics } \\
\text { model of switchgrass for cellulosic ethanol production in the U.S. midwest }\end{array}$ \\
\hline Kemper \& Partzsch, 2018 & $\begin{array}{l}\text { A water sustainability framework for assessing biofuel certification schemes: } \\
\text { Does European hybrid governance ensure sustainability of palm oil } \\
\text { from Indonesia? }\end{array}$ \\
\hline
\end{tabular}


Table A1. Cont.

\begin{tabular}{|c|c|}
\hline Author, Year & Article \\
\hline Kgathi et al., 2017 & $\begin{array}{l}\text { A review of the sustainability of Jatropha cultivation projects for biodiesel } \\
\text { production in southern Africa: Implications for energy policy in Botswana }\end{array}$ \\
\hline Kuti et al., 2017 & $\begin{array}{l}\text { Rural-urban disparity in lung function parameters of Nigerian children: Effects } \\
\text { of socio-economic, nutritional and housing factors }\end{array}$ \\
\hline Lim \& Biswas, 2019 & $\begin{array}{l}\text { Sustainability implications of the incorporation of a biogas trapping system into } \\
\text { a conventional crude palm oil supply chain }\end{array}$ \\
\hline $\begin{array}{l}\text { Lehtonen \& } \\
\text { Okkonen, } 2016\end{array}$ & $\begin{array}{l}\text { Socio-Economic impacts of a local bioenergy-based development strategy-The } \\
\text { case of Pielinen Karelia, Finland }\end{array}$ \\
\hline Luqman et al., 2018 & $\begin{array}{l}\text { Socio-Economic impacts of agro-forestry on livelihoods of rural households in } \\
\text { southern region of the Punjab, Pakistan }\end{array}$ \\
\hline Machado et al., 2017 & $\begin{array}{l}\text { Analysis of socioeconomic and environmental sensitivity of sugarcane } \\
\text { cultivation using a Geographic Information System }\end{array}$ \\
\hline Maconachie, 2019 & $\begin{array}{l}\text { Green grabs and rural development: How sustainable is biofuel production in } \\
\text { post-war Sierra Leone? }\end{array}$ \\
\hline Mahbub et al., 2019 & $\begin{array}{l}\text { A life cycle sustainability assessment (LCSA) of oxymethylene ether as a diesel } \\
\text { additive produced from forest biomass }\end{array}$ \\
\hline Meeks et al., 2019 & Waste Not: Can Household Biogas Deliver Sustainable Development? \\
\hline Nguyen et al., 2017 & $\begin{array}{l}\text { Inclusive impact assessment for the sustainability of vegetable oil-based } \\
\text { biodiesel-Part II: Sustainability assessment of inedible vegetable oil-based } \\
\text { biodiesel in Ha Long Bay, Vietnam }\end{array}$ \\
\hline $\begin{array}{l}\text { Nishiguchi \& } \\
\text { Tabata, } 2016\end{array}$ & $\begin{array}{l}\text { Assessment of social, economic, and environmental aspects of woody biomass } \\
\text { energy utilization: Direct burning and wood pellets }\end{array}$ \\
\hline Ofuoku \& Oghene, 2017 & $\begin{array}{l}\text { Socioeconomic effects of land grab on farming household }(\mathrm{HH}) \text { heads in Delta } \\
\text { Central Agricultural Zone, Delta State, Nigeria }\end{array}$ \\
\hline Oliveira et al., 2019 & $\begin{array}{l}\text { Is the expansion of sugarcane over pasturelands a sustainable strategy for } \\
\text { Brazil's bioenergy industry? }\end{array}$ \\
\hline Papong et al., 2017 & $\begin{array}{l}\text { Environmental life cycle assessment and social impacts of bioethanol } \\
\text { production in Thailand }\end{array}$ \\
\hline Petrini et al., 2017 & $\begin{array}{l}\text { Mismatches between mill-cultivated sugarcane and smallholding farming in } \\
\text { Brazil: Environmental and socioeconomic impacts }\end{array}$ \\
\hline Rahman et al., 2019 & $\begin{array}{l}\text { Implementation of bioenergy systems towards achieving United Nations' } \\
\text { sustainable development goals in rural Bangladesh }\end{array}$ \\
\hline Rakotovao et al., 2018 & $\begin{array}{l}\text { Developing a socio-economic framework for the assessment of rural } \\
\text { biorefinery projects }\end{array}$ \\
\hline Schelhas et al., 2018 & Envisioning and Implementing Sustainable Bioenergy Systems in the U.S. South \\
\hline Warren et al., 2016 & $\begin{array}{l}\text { Limited adoption of short rotation coppice: The role of farmers' socio-cultural } \\
\text { identity in influencing practice }\end{array}$ \\
\hline Yasar et al., 2017 & $\begin{array}{l}\text { Socio-economic, health and agriculture benefits of rural household biogas plants } \\
\text { in energy scarce developing countries: A case study from Pakistan }\end{array}$ \\
\hline
\end{tabular}


Appendix A.2

Table A2. Social aspects proposed in the Methodological Sheets for Subcategories in S-LCA [19].

\begin{tabular}{|c|c|c|c|c|}
\hline Workers & Local Community & Society & Value Chain Actors & Consumer \\
\hline $\begin{array}{l}\text { Freedom of } \\
\text { Association and } \\
\text { Collective } \\
\text { Bargaining }\end{array}$ & $\begin{array}{l}\text { Delocalization } \\
\text { and Migration }\end{array}$ & $\begin{array}{ll}- & \text { Public } \\
\text { Commitment to } \\
\text { Sustainability } \\
\text { Issues }\end{array}$ & $\begin{array}{ll}-\quad & \text { Fair } \\
& \text { Competition }\end{array}$ & $\begin{array}{l}\text { - Health and } \\
\text { Safety }\end{array}$ \\
\hline - Child Labour & $\begin{array}{l}\text { - Community } \\
\text { Engagement }\end{array}$ & $\begin{array}{l}\text { Prevention or } \\
\text { Mitigation of } \\
\text { Conflicts }\end{array}$ & $\begin{array}{ll}\text { - } & \text { Respect of } \\
\text { Intellectual } \\
\text { Property Rights }\end{array}$ & $\begin{array}{ll}\text { - } & \text { Feedback } \\
\text { Mechanism }\end{array}$ \\
\hline - $\quad$ Fair Salary & $\begin{array}{l}\text { Cultural } \\
\text { Heritage }\end{array}$ & $\begin{array}{l}\text { - Contribution to } \\
\text { Economic } \\
\text { Develpment }\end{array}$ & $\begin{array}{ll}\text { - } & \text { Supplier } \\
& \text { Relationships }\end{array}$ & - $\quad$ Privacy \\
\hline - Hours of Work & $\begin{array}{ll}- & \text { Respect of } \\
\text { Indigenous } \\
\text { Rights } \\
\end{array}$ & - Corruption & $\begin{array}{ll}- & \text { Promoting } \\
\text { Social } \\
\text { Responsibility } \\
\end{array}$ & - Transparency \\
\hline - Forced Labour & $\begin{array}{ll}\text { - } & \text { Local } \\
\text { Employment }\end{array}$ & $\begin{array}{ll}\text { - } & \text { Technology } \\
& \text { Development }\end{array}$ & & $\begin{array}{ll}\text { - } & \text { End-of-Life- } \\
& \text { Responsibility }\end{array}$ \\
\hline $\begin{array}{ll} & \text { Equal } \\
\text { Opportunities/ } \\
\text { Discrimination }\end{array}$ & $\begin{array}{ll}- & \text { Access to } \\
\text { Immaterial } \\
\text { Resources }\end{array}$ & & & \\
\hline $\begin{array}{l}\text { - Health and } \\
\text { Safety }\end{array}$ & $\begin{array}{ll}- & \text { Access to } \\
\text { Material } \\
\text { Resources }\end{array}$ & & & \\
\hline $\begin{array}{ll} & \text { Social } \\
\text { Benefit/Social } \\
\text { Security }\end{array}$ & $\begin{array}{ll}\text { - } & \text { Safe and } \\
\text { Healthy Living } \\
\text { Conditions }\end{array}$ & & & \\
\hline & $\begin{array}{ll} & \text { Secure Living } \\
& \text { Conditions }\end{array}$ & & & \\
\hline
\end{tabular}

\section{References}

1. Piotrowski, S.; Carus, M.; Essel, R. Sustainable biomass supply and demand: A scenario analysis. Open Agric. 2016, 1, 18-28. [CrossRef]

2. German Bioeconomy Council. Bioeconomy Policy (Part III)—Update Report of National Strategies around the World. 2018. Available online: https:/ / biooekonomierat.de/fileadmin/Publikationen/berichte/GBS_ 2018_Bioeconomy-Strategies-around-the_World_Part-III.pdf (accessed on 19 August 2020).

3. Urban, K.; Schiesari, C.; Boysen, O.; Hahn, R.; Wagner, M.; Lewandowski, I.; Kuckertz, A.; Berger, E.S.C.; Reyes, C.A.M. Markets, Sustainability Management and Entrepreneurship. In Bioeconomy: Shaping the Transition to a Sustainable, Biobased Economy; Lewandowski, I., Ed.; Springer International Publishing: Cham, Switzerland, 2018; pp. 231-286. [CrossRef]

4. Falcone, P.M.; González García, S.; Imbert, E.; Lijó, L.; Moreira, M.T.; Tani, A.; Tartiu, V.E.; Morone, P. Transitioning towards the bio-economy: Assessing the social dimension through a stakeholder lens. Corp. Soc. Responsib. Environ. Manag. 2019, 26, 1135-1153. [CrossRef]

5. Fuentes-Saguar, P.D.; Mainar-Causapé, A.J.; Ferrari, E. The role of bioeconomy sectors and natural resources in EU economies: A social accounting matrix-based analysis approach. Sustainability 2017, 9, 2383. [CrossRef]

6. Li, J.; Zhang, Z.; Jin, X.; Chen, J.; Zhang, S.; He, Z.; Li, S.; He, Z.; Zhang, H.; Xiao, H. Exploring the socioeconomic and ecological consequences of cash crop cultivation for policy implications. Land Use Policy 2018, 76, 46-57. [CrossRef]

7. Novo, A.; Jansen, K.; Slingerland, M.; Giller, K. Biofuel, dairy production and beef in Brazil: competing claims on land use in São Paulo state. J. Peasant Stud. 2010, 37, 769-792. [CrossRef] [PubMed]

8. Diaz-Chavez, R.; Haye, S.; Dörnbrack, A.S.; Rutz, D.; Janssen, R. Recommendations on the Integration of Socio-Economic Sustainability Criteria in European Legislation and Policies. 2013. Available online: http:/ / www.globalbiopact.eu/publications.html (accessed on 26 August 2020). 
9. Cadena, E.; Rocca, F.; Gutierrez, J.A.; Carvalho, A. Social life cycle assessment methodology for evaluating production process design: Biorefinery case study. J. Clean. Prod. 2019, 238, 117718. [CrossRef]

10. Renzaho, A.M.N.; Kamara, J.K.; Toole, M. Biofuel production and its impact on food security in low and middle income countries: Implications for the post-2015 sustainable development goals. Renew. Sustain. Energy Rev. 2017, 78, 503-516. [CrossRef]

11. Kiggundu, N.; Arhin, S.G.; Banadda, N.; Kabenge, I. Impacts of biofuel policies on welfare and food security: Assessing the socioeconomic and environmental trade-offs in sub-Saharan Africa. Int. J. Renew. Energy Res. 2017, 7, 2162-2171.

12. Kamali, F.P.; Borges, J.A.R.; Osseweijer, P.; Posada, J.A. Towards social sustainability: Screening potential social and governance issues for biojet fuel supply chains in Brazil. Renew. Sustain. Energy Rev. 2018, 92, 50-61. [CrossRef]

13. German, L.; Goetz, A.; Searchinger, T.; de LT Oliveira, G.; Tomei, J.; Hunsberger, C.; Weigelt, J. Sine Qua Nons of sustainable biofuels: Distilling implications of under-performance for national biofuel programs. Energy Policy 2017, 108, 806-817. [CrossRef]

14. Rafiaani, P.; Kuppens, T.; Van Dael, M.; Azadi, H.; Lebailly, P.; Van Passel, S. Social sustainability assessments in the biobased economy: Towards a systemic approach. Renew. Sustain. Energy Rev. 2018, 82, 1839-1853. [CrossRef]

15. UNEP-SETAC Life Cycle Initiative. Guidelines for Social Life Cycle Assessment of Products; Social and Socio-Economic LCA Guidelines Complementing Environmental LCA and Life Cycle Costing, Contributing to the Full Assessment of Goods and Services within the Context of Sustainable Development; UNEP: Paris, France, 2009.

16. International Organization for Standardization (ISO). ISO 14044:2006. Environmental Management: Life Cycle Assessment; Requirements and Guidelines. 2006. Available online: https://www.iso.org/ standard/38498.html (accessed on 20 September 2020).

17. International Organization for Standardization (ISO). ISO 14040:2006. Environmental Management: Life Cycle Assessment; Requirements and Guidelines. 2006. Available online: https://www.iso.org/ standard/37456.html (accessed on 20 September 2020).

18. Siebert, A.; Bezama, A.; O'Keeffe, S.; Thrän, D. Social life cycle assessment indices and indicators to monitor the social implications of wood-based products. J. Clean. Prod. 2018, 172, 4074-4084. [CrossRef]

19. Benoît Norris, C.; Traverso, M.; Valdivia, S.; Vickery-Niederman, G.; Franze, J.; Azuero, L.; Ciroth, A.; Mazijn, B.; Aulisio, D. The Methodological Sheets for Sub-Categories in Social Life Cycle Assessment (S-LCA). UNEP and SETAC. 2013. Available online: https://www.lifecycleinitiative.org/wp-content/ uploads/2013/11/S-LCA_methodological_sheets_11.11.13.pdf (accessed on 20 October 2020).

20. UN Environment, S.A. Guidelines for Social Life Cycle Assessment-V3 Draft. 2020. Available online: https: / / slcaguidelines.konveio.com/guidelines-social-life-cycle-assessment-v3-draft (accessed on 28 August 2020).

21. Lewandowski, I.; Lippe, M.; Montoya, J.C.; Dickhöfer, U.; Langenberger, G.; Pucher, J.; Schließmann, U.; Schmid-Staiger, U.; Derwenskus, F.; Lippert, C. Primary Production. In Bioeconomy: Shaping the Transition to a Sustainable, Biobased Economy; Lewandowski, I., Ed.; Springer International Publishing: Cham, Switzerland, 2018; pp. 97-178. [CrossRef]

22. International Labour Organization (ILO). Industries and Sectors. Available online: https://www.ilo.org/ global/industries-and-sectors/agriculture-plantations-other-rural-sectors/lang--en/index.htm (accessed on 22 September 2020).

23. Food and Agriculture Organization (FAO). The Global Bioenergy Partnership Sustainability Indicators for Bioenergy. 2011. Available online: http:/ /www.globalbioenergy.org/fileadmin/user_upload/gbep/docs/ Indicators / Report_HYPERLINK_updated_CM_25-05-2017.pdf (accessed on 12 September 2020).

24. Global-Bio-Pact. Global Assessment of Biomass and Bioproduct Impacts on Socio-Economics and Sustainability; FP7 EU Funded Project; European Commission: Brussels, Belgium, 2012.

25. Hasenheit, M.; Gerdes, H.; Kiresiewa, Z.; Beekman, V. Summary Report on Social, Economic and Environment Impacts of the Bioeconomy. 2016. Available online: http://www.bio-step.eu/fileadmin/ BioSTEP / Bio_documents/BioSTEP_D2.2_Impacts_of_the_bioeconomy.pdf (accessed on 12 September 2020).

26. Martin, M.; Røyne, F.; Ekvall, T.; Moberg, Å. Life cycle sustainability evaluations of bio-based value chains: reviewing the indicators from a Swedish perspective. Sustainability 2018, 10, 547. [CrossRef]

27. van Schoubroeck, S.; van Dael, M.; van Passel, S.; Malina, R. A review of sustainability indicators for biobased chemicals. Renew. Sustain. Energy Rev. 2018, 94, 115-126. [CrossRef] 
28. Huertas-Valdivia, I.; Ferrari, A.M.; Settembre-Blundo, D.; García-Muiña, F.E. Social Life-Cycle Assessment: A Review by Bibliometric Analysis. Sustainability 2020, 12, 6211. [CrossRef]

29. Bhutto, A.W.; Bazmi, A.A.; Karim, S.; Abro, R.; Mazari, S.A.; Nizamuddin, S. Promoting sustainability of use of biomass as energy resource: Pakistan's perspective. Environ. Sci. Pollut. Res. 2019, 26, 29606-29619. [CrossRef]

30. PRISMA. Available online: http://www.prisma-statement.org/ (accessed on 22 September 2020).

31. SDG Indicators-Regional Groupings Used in Report and Statistical Annex. Available online: http://unstats. un.org/sdgs/indicators/regional-groups / (accessed on 24 June 2020).

32. Altenbuchner, C.; Vogel, S.; Larcher, M. Social, economic and environmental impacts of organic cotton production on the livelihood of smallholder farmers in Odisha, India. Renew. Agric. Food Syst. 2018, 33, $373-385$. [CrossRef]

33. Bohra, B.; Sharma, N.; Saxena, S.; Sabhlok, V.; Ramakrishna, Y.B. Socio-economic impact of biofuel agroforestry systems on smallholder and large-holder farmers in Karnataka, India. Agrofor. Syst. 2018, 92, 759-774. [CrossRef]

34. Luqman, M.; Saqib, R.; Karim, M.; Nawab, K.; Rehman, A.; Yaseen, M. Socio-economic impacts of agro-forestry on livelihoods of rural households in southern region of the Punjab, Pakistan. Sarhad J. Agric. 2018, 34, 880-887. [CrossRef]

35. Meeks, R.; Sims, K.R.E.; Thompson, H. Waste not: Can household biogas deliver sustainable development? Environ. Resour. Econ. 2019, 72, 763-794. [CrossRef]

36. Rahman, K.M.; Edwards, D.J.; Melville, L.; El-Gohary, H. Implementation of Bioenergy Systems towards Achieving United Nations' Sustainable Development Goals in Rural Bangladesh. Sustainability 2019, 11, 3814. [CrossRef]

37. Yasar, A.; Nazir, S.; Tabinda, A.B.; Nazar, M.; Rasheed, R.; Afzaal, M. Socio-economic, health and agriculture benefits of rural household biogas plants in energy scarce developing countries: A case study from Pakistan. Renew. Energy 2017, 108, 19-25. [CrossRef]

38. Bentzen, J.; Truc, N.T.T.; Nam, T.S. A social cost-benefit analysis of biogas technologies using rice straw and water hyacinths as feedstock. Int. Energy J. 2018, 18, 311-320.

39. Kemper, L.; Partzsch, L. A water sustainability framework for assessing biofuel certification schemes: Does European hybrid governance ensure sustainability of palm oil from Indonesia. J. Clean. Prod. 2018, 192, 835-843. [CrossRef]

40. Lim, C.I.; K Biswas, W. Sustainability implications of the incorporation of a biogas trapping system into a conventional crude palm oil supply chain. Sustainability 2019, 11, 792. [CrossRef]

41. Nguyen, T.A.; Maeda, Y.; Kuroda, K.; Otsuka, K. Inclusive impact assessment for the sustainability of vegetable oil-based biodiesel-Part II: Sustainability assessment of inedible vegetable oil-based biodiesel in Ha Long Bay, Vietnam. J. Clean. Prod. 2017, 168, 173-188. [CrossRef]

42. Papong, S.; Rewlay-Ngoen, C.; Itsubo, N.; Malakul, P. Environmental life cycle assessment and social impacts of bioethanol production in Thailand. J. Clean. Prod. 2017, 157, 254-266. [CrossRef]

43. Nishiguchi, S.; Tabata, T. Assessment of social, economic, and environmental aspects of woody biomass energy utilization: Direct burning and wood pellets. Renew. Sustain. Energy Rev. 2016, 57, 1279-1286. [CrossRef]

44. Interlenghi, S.F.; de Almeida Bruno, P.; de Queiroz Fernandes, A.O.; de Medeiros, J.L. Social and environmental impacts of replacing transesterification agent in soybean biodiesel production: multi-criteria and principal component analyses. J. Clean. Prod. 2017, 168, 149-162. [CrossRef]

45. Machado, P.G.; Rampazo, N.A.M.; Picoli, M.C.A.; Miranda, C.G.; Duft, D.G.; de Jesus, K.R.E. Analysis of socioeconomic and environmental sensitivity of sugarcane cultivation using a Geographic Information System. Land Use Policy 2017, 69, 64-74. [CrossRef]

46. Maconachie, R. Green grabs and rural development: How sustainable is biofuel production in post-war Sierra Leone? Land Use Policy 2019, 81, 871-877. [CrossRef]

47. Oliveira, D.M.S.; Cherubin, M.R.; Franco, A.L.C.; Santos, A.S.; Gelain, J.G.; Dias, N.M.S.; Diniz, T.R.; Almeida, A.N.; Feigl, B.J.; Davies, C.A. Is the expansion of sugarcane over pasturelands a sustainable strategy for Brazil's bioenergy industry? Renew. Sustain. Energy Rev. 2019, 102, 346-355. [CrossRef]

48. Petrini, M.A.; Rocha, J.V.; Brown, J.C. Mismatches between mill-cultivated sugarcane and smallholding farming in Brazil: Environmental and socioeconomic impacts. J. Rural. Stud. 2017, 50, 218-227. [CrossRef] 
49. Bautista, S.; Espinoza, A.; Narvaez, P.; Camargo, M.; Morel, L. A system dynamics approach for sustainability assessment of biodiesel production in Colombia. Baseline simulation. J. Clean. Prod. 2019, 213, 1-20. [CrossRef]

50. Ofuoku, A.U.; Oghene, E.E. Socioeconomic effect of land grab on farming household (HH) heads in Delta Central Agricultural Zone, Delta State, Nigeria. J. Agric. Environ. Int. Dev. (JAEID) 2017, 111, 75-85.

51. Gabisa, E.W.; Gheewala, S.H. Potential, environmental, and socio-economic assessment of biogas production in Ethiopia: The case of Amhara regional state. Biomass Bioenergy 2019, 122, 446-456. [CrossRef]

52. Cavicchi, B.; Palmieri, S.; Odaldi, M. The influence of local governance: Effects on the sustainability of bioenergy innovation. Sustainability 2017, 9, 406. [CrossRef]

53. Brewer, J.P., II; Vandever, S.; Johnson, J.T. Towards energy sovereignty: Biomass as sustainability in interior Alaska. Sustain. Sci. 2018, 13, 417-429. [CrossRef]

54. Husgafvel, R.; Poikela, K.; Honkatukia, J.; Dahl, O. Development and Piloting of Sustainability Assessment Metrics for Arctic Process Industry in Finland-The Biorefinery Investment and Slag Processing Service Cases. Sustainability 2017, 9, 1693. [CrossRef]

55. Jasinevičius, G.; Lindner, M.; Verkerk, P.J.; Aleinikovas, M. Assessing impacts of wood utilisation scenarios for a Lithuanian bioeconomy: Impacts on carbon in forests and harvested wood products and on the socio-economic performance of the forest-based sector. Forests 2017, 8, 133. [CrossRef]

56. Mahbub, N.; Oyedun, A.O.; Zhang, H.; Kumar, A.; Poganietz, W.R. A life cycle sustainability assessment (LCSA) of oxymethylene ether as a diesel additive produced from forest biomass. Int. J. Life Cycle Assess. 2019, 24, 881-899. [CrossRef]

57. Lehtonen, O; Okkonen, L. Socio-economic impacts of a local bioenergy-based development strategy-The case of Pielinen Karelia, Finland. Renew. Energy 2016, 85, 610-619. [CrossRef]

58. Schelhas, J.; Hitchner, S.; Brosius, J.P. Envisioning and implementing sustainable bioenergy systems in the US South. In Handbook of Sustainability and Social Science Research; Springer: Berlin, Garmany, 2018; pp. 301-314.

59. Rapsomanikis, G. The Economic Lives of Smallholder Farmers: An Analysis Based on Household Data from Nine Countries; Food and Agriculture Organization of the United Nations: Rome, Italy, 2015. Available online: http:/ / www.fao.org/3/a-i5251e.pdf (accessed on 27 August 2020).

60. Augustine, U.; Chinwe, O.; Anthony, I.; Ukpere, W. Economic and social issues related to foreign land grab and capacity building in Zambian Agricultural economy. Probl. Perspect. Manag. 2016, 14, $236-246$. [CrossRef]

61. Barros Ribeiro, E.C.; Moreira, A.C.; Ferreira, L.M.D.; da Silva César, A. Biodiesel and social inclusion: An analysis of institutional pressures between biodiesel plants and family farmers in southern Brazil. J. Clean. Prod. 2018, 204, 726-734. PII: S0959652618328051. [CrossRef]

62. Costa, M.P.; Schoeneboom, J.C.; Oliveira, S.A.; Vinas, R.S.; de Medeiros, G.A. A socio-eco-efficiency analysis of integrated and non-integrated crop-livestock-forestry systems in the Brazilian Cerrado based on LCA. J. Clean. Prod. 2018, 171, 1460-1471. [CrossRef]

63. Warren, C.R.; Burton, R.; Buchanan, O.; Birnie, R.V. Limited adoption of short rotation coppice: The role of farmers' socio-cultural identity in influencing practice. J. Rural Stud. 2016, 45, 175-183. [CrossRef]

64. Lowder, S.K.; Skoet, J.; Raney, T. The number, size, and distribution of farms, smallholder farms, and family farms worldwide. World Dev. 2016, 87, 16-29. [CrossRef]

65. Nagayets, O. Small farms: Current status and key trends. In Proceedings of the Future of Small Farms, Wye, UK, 26-29 June 2005.

66. Blanc, S.; Massaglia, S.; Brun, F.; Peano, C.; Mosso, A.; Giuggioli, N.R. Use of Bio-Based Plastics in the Fruit Supply Chain: An Integrated Approach to Assess Environmental, Economic, and Social Sustainability. Sustainability 2019, 11, 2475. [CrossRef]

67. Cong, R.G.; Stefaniak, I.; Madsen, B.; Dalgaard, T.; Jensen, J.D.; Nainggolan, D.; Termansen, M. Where to implement local biotech innovations? A framework for multi-scale socio-economic and environmental impact assessment of Green Bio-Refineries. Land Use Policy 2017, 68, 141-151. [CrossRef]

68. Jin, E.; Mendis, G.P.; Sutherland, J.W. Integrated sustainability assessment for a bioenergy system: A system dynamics model of switchgrass for cellulosic ethanol production in the U.S. midwest. J. Clean. Prod. 2019, 234, 503-520. [CrossRef]

69. Horn, R.; Dahy, H.; Gantner, J.; Speck, O.; Leistner, P. Bio-inspired sustainability assessment for building product development—concept and case study. Sustainability 2018, 10, 130. [CrossRef] 
70. Rakotovao, M.; Gobert, J.; Brullot, S. Developing a socio-economic framework for the assessment of rural biorefinery projects. In Proceedings of the 26th European Biomass Conference and Exhibition, Copenhagen, Denmark, 14-17 May 2018.

71. Kuti, B.P.; Oladimeji, O.I.; Kuti, D.K.; Adeniyi, A.T.; Adeniji, E.O.; Osundare, Y.J. Rural-urban disparity in lung function parameters of Nigerian children: Effects of socio-economic, nutritional and housing factors. Pan Afr. Med. J. 2017, 28. [CrossRef] [PubMed]

72. World Bank. Sustainable Energy for All (SE4ALL) Database from WHOM Global Household Energy Database. Available online: https://data.worldbank.org/indicator/EG.CFT.ACCS.ZS (accessed on 24 June 2020).

73. International Labour Organization (ILO). Global Estimates of Child Labour: Results and Trends 2012-2016. 2017. Available online: https://www.ilo.org/global/publications/books/WCMS_575499/lang--en/index. htm (accessed on 27 August 2020).

74. Heidari, A.; Hajinezhad, A.; Aslani, A. A sustainable power supply system, Iran's opportunities via bioenergy. Environ. Prog. Sustain. Energy 2019, 38, 171-188. [CrossRef]

75. Kgathi, D.L.; Mmopelwa, G.; Chanda, R.; Kashe, K.; Murray-Hudson, M. A review of the sustainability of Jatropha cultivation projects for biodiesel production in southern Africa: Implications for energy policy in Botswana. Agric. Ecosyst. Environ. 2017, 246, 314-324. [CrossRef]

76. Phillips, F.K. Sustainable bio-based supply chains in light of the Nagoya Protocol. In Freedom-Kai Phillips, "Sustainable Bio-Based Supply Chains in Light of the Nagoya Protocol" in Wendy Tate; Implementing Triple Bottom Line Sustainability into Global Supply Chains; Greenleaf Publishing: London, UK, 2016. Available online: https: / ssrn.com/abstract=3033039 (accessed on 27 August 2020).

77. Anuar, M.R.; Abdullah, A.Z. Challenges in biodiesel industry with regards to feedstock, environmental, social and sustainability issues: A critical review. Renew. Sustain. Energy Rev. 2016, 58, 208-223. [CrossRef]

78. International Finance Corporation (IFC). Guidance Note 5: Land Acquisition and Involuntary Resettlement. 2012. Available online: https://www.ifc.org/wps/wcm/connect/topics_ext_content/ifc_ external_corporate_site/sustainability-at-ifc/policies-standards/performance-standards/ps5 (accessed on 27 August 2020).

79. Terminski, B. Development-Induced Displacement and Resettlement: Causes, Consequences, and Socio-Legal Context; Columbia University Press: New York, NY, USA, 2014.

80. Garnett, S.T.; Burgess, N.D.; Fa, J.E.; Fernández-Llamazares, Á.; Molnár, Z.; Robinson, C.J.; Watson, J.E.; Zander, K.K.; Austin, B.; Brondizio, E.S.; et al. A spatial overview of the global importance of Indigenous lands for conservation. Nat. Sustain. 2018, 1, 369. [CrossRef]

81. Naiman, J. ANILCA Section 810: An Undervalued Protection for Alaskan Villagers' Subsistance. Fordham Environ. Law J. 1995, 7, 211.

82. Efferth, T.; Banerjee, M.; Paul, N.W.; Abdelfatah, S.; Arend, J.; Elhassan, G.; Hamdoun, S.; Hamm, R.; Hong, C.; Kadioglu, O.; et al. Biopiracy of natural products and good bioprospecting practice. Phytomedicine 2016, 23, 166-173. [CrossRef]

83. Ekener, E.; Hansson, J.; Gustavsson, M. Addressing positive impacts in social LCA—discussing current and new approaches exemplified by the case of vehicle fuels. Int. J. Life Cycle Assess. 2018, 23, 556-568. [CrossRef]

84. van Eijck, J.; Batidzirai, B.; Faaij, A. Current and future economic performance of first and second generation biofuels in developing countries. Appl. Energy 2014, 135, 115-141. [CrossRef]

85. Thomas, G.; De Tavernier, J. Farmer-suicide in India: Debating the role of biotechnology. Life Sci. Soc. Policy 2017, 13, 8. [CrossRef] [PubMed]

86. Messmer, M.M.; Shivas, Y.; Verma, R.; Ramprasad, S.; Ambatibudi, A.; Patil, S.S. Participatory Cotton breeding and cultivar Evaluation for organic smallholders in India. Build. Org. Bridg. 2014, 2, 671-674.

87. Brief, F.P. Food Security. FAO Agriculture and Development Economics Division. 2006. Available online: http: / / www.fao.org/fileadmin/templates/faoitaly/documents/pdf/pdf_Food_Security_Cocept_Note.pdf (accessed on 27 August 2020).

88. Alexander, C.; Hurt, C. Biofuels and Their Impact on Food Prices. 2007. Available online: https://www. extension.purdue.edu/extmedia/ID/ID-346-W.pdf (accessed on 28 August 2020).

89. Von Maltitz, G.P.; Setzkorn, K.A. A typology of Southern African biofuel feedstock production projects. Biomass Bioenergy 2013, 59, 33-49. [CrossRef] 
90. Haider, T.P.; Völker, C.; Kramm, J.; Landfester, K.; Wurm, F.R. Plastics of the future? The impact of biodegradable polymers on the environment and on society. Angew. Chem. Int. Ed. 2019, 58, 50-62. [CrossRef] [PubMed]

91. Poku, A.G.; Birner, R.; Gupta, S. Making contract farming arrangements work in Africa's bioeconomy: Evidence from cassava outgrower schemes in Ghana. Sustainability 2018, 10, 1604. [CrossRef]

92. Bissonnette, J.F.; De Koninck, R. Social and Environmental Implications of Plantation Agriculture in Malaysia and Indonesia. Oxford Research Encyclopedia of Environmental Science. 2017. Available online: https: / / oxfordre.com/environmentalscience/view/10.1093/acrefore/9780199389414.001. 0001/acrefore-9780199389414-e-207 (accessed on 22 August 2020).

93. Fuchs, G. The bioenergy village movement in Germany-agrarian backwardness or future oriented re-organisation of the energy system? Soc. Ekol. 2016, 25, 103-120.

94. Marks, D.; Sirithet, A.; Rakyuttitham, A.; Wulandari, S.; Chomchan, S.; Samranjit, P. Land Grabbing and Impacts to Small Scale Farmers in Southeast Asia Sub-Region; Paper series of the Conference Programme of the International; Institute of Social Studies in The Hague: The Hague, The Netherlands, 2015. Available online: www.landactionthai.org (accessed on 22 September 2020).

95. Kay, S.; Peuch, J.; Franco, J. Extent of Farmland Grabbing in the EU; Technical Report; Study for the European Parliament's Committee on Agriculture and Rural Development. 2015. Available online: https: / / www.europarl.europa.eu/thinktank/en/document.html?reference=IPOL_STU(2015)540369 (accessed on 27 August 2020).

96. Gasparatos, A.; von Maltitz, G.P.; Johnson, F.X.; Lee, L.; Mathai, M.; de Oliveira, J.P.; Willis, K.J. Biofuels in sub-Sahara Africa: Drivers, impacts and priority policy areas. Renew. Sustain. Energy Rev. 2015, 45, 879-901. [CrossRef]

97. D'Orfeuil, H.R. The Exclusion of Farmers: A Historical Challenge for the International Labour Market. S.A.P.I.EN.S. Surveys and Perspectives Integrating Environment and Society. 2012. Available online: http:/ /journals.openedition.org/sapiens/1487 (accessed on 27 August 2020).

98. Sureau, S.; Lohest, F.; Van Mol, J.; Bauler, T.; Achten, W.M. Participation in S-LCA: A Methodological Proposal Applied to Belgian Alternative Food Chains (Part 1). Resources 2019, 8, 160. [CrossRef]

99. Zira, S.; Röös, E.; Ivarsson, E.; Hoffmann, R.; Rydhmer, L. Social life cycle assessment of Swedish organic and conventional pork production. Int. J. Life Cycle Assess. 2020, 25, 1957-1975. [CrossRef]

100. Prasara-A, J.; Gheewala, S.H. Social Life Cycle Assessment of Agricultural Products: Experiences on Rice, Sugarcane and Cassava in Thailand. In Social Life Cycle Assessment; Springer: Berlin, Germany, 2019; pp. 1-37.

Publisher's Note: MDPI stays neutral with regard to jurisdictional claims in published maps and institutional affiliations.

(C) 2020 by the authors. Licensee MDPI, Basel, Switzerland. This article is an open access article distributed under the terms and conditions of the Creative Commons Attribution (CC BY) license (http://creativecommons.org/licenses/by/4.0/). 